\title{
Dolomite-illitic rocks (dolillite) - the product of hydrothermal replacement of carbonate rocks in the Holy Cross Mts., Poland - a possible guide to ores
}

\author{
Marek NIEĆ ${ }^{1, *}$ and Maciej PAWLIKOWSKI \\ 1 Polish Academy of Sciences, Mineral and Energy Economy Research Institute, Wybickiego 7A, 31-261 Kraków, Poland \\ 2 AGH University of Science and Technology, al. A. Mickiewicza 30, 30-059 Kraków, Poland
}

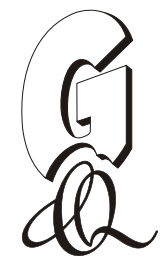

Nieć, M., Pawlikowski, M., 2019. Dolomite-illitic rocks (dolillite) - the product of hydrothermal replacement of carbonate rocks in the Holy Cross Mts., Poland - a possible guide to ores. Geological Quarterly, 63 (2): 275-295, doi: 10.7306/gq.1474

Associate editor: Stanisław Mikulski

The dolomites altered to dolomite-illitic rocks were found accompanying marcasite-pyrite-hematite mineralization within the Middle Devonian carbonate rocks in the eastern part of the Holy Cross Mts. (Poland) in the fault zones and their close vicinity. The alteration consist of dolomite recrystallization and replacement by illite, accompanied by small amounts of silica, K-feldspars and disseminated pyrite or hematite. The final product of dolomite replacement by illite are massive, dolomite-illitic rocks unevenly distributed within the unaltered dolomites or in fault breccia. They form irregular metric-sized nest-like bodies most often with blurred boundaries, or in some places sharp delineated veins and lenses. Illite crystallinity, demonstrates its hydrothermal origin. Altered rocks are characterized by elevated contents of REE, Rb, and sometimes other trace metal ( $\mathrm{Zr}, \mathrm{Ti}, \mathrm{Zn}, \mathrm{U}, \mathrm{Th}, \mathrm{Ba}$ and al. ), compared to unaltered dolomites. The enrichment in $\mathrm{REE}, \mathrm{Zr}$ and Ti implies their mobility in hydrothermal solutions. The lamprophyre intrusions present in the close vicinity may be considered as the probable source of potassium rich hydrothermal fluids. The peculiar features of dolomite-illitic rocks such as: their composition and occurrence close to the sulphide and hematite mineralization, allow supposing, that they may be a guide to deeply seated unknown ore deposits.

Key words: dolomite, illite, hydrothermal replacement.

\section{INTRODUCTION}

In the Holy Cross Mts. a peculiar replacement of Middle Devonian dolomites by illite was noticed. It have led to the formation of irregular bodies of dolomite-illitic rocks. Their widespread appearance, within tectonically disturbed dolomites close to marcasite-pyrite-hematite mineralization, the irregular mode of occurrence, mineral composition, petrographic features and trace element content may be related to the specific hydrothermal rock alteration, and may be considered as a possible guide to the hidden hydrothermal ore deposits. Below we present the preliminary study of these uncommon dolomite-illitic rocks.

Hydrothermal argillaceous rock alteration is a well-recognized phenomenon accompanying ore deposits within igneous and metamorphic alumosilicate rocks. It is seldom reported in carbonate rocks. Lovering and Shepard (1960) observed and studied this type of alteration in the Tintic (Utah, US) ore de-

\footnotetext{
* Corresponding author, e-mail: niecm@wp.pl
}

Received: September 21, 2018; accepted: February 18, 2019; first published online: May 28, 2019 posit, where dolomite, near the contact with argilized quartz rhyolite (latite), was replaced partly by fluorite accompanied by kaolinite and diaspore and at some distance by smectite-illite. Clay minerals appearing within the aureole of the ore deposits located in carbonate rocks are considered as a residual products of carbonate removal, e.g. by hydrothermal karstification. Their transformations to the well-ordered varieties (Heyl et al., 1964) or reprecipitation (Mattoussi Kort et al., 2008) are reported. Clay minerals that may be the direct hydrothermal product are rarely noticed. Hosterman et al. (1964) suggested a hydrothermal formation of illite in the aureole of the Mississippi Valley zinc-lead deposits. In the Kraków-Silesian zinc-lead MV-type deposit, small quantities of allophane were found (Bąk and Nieć, 1979). Haloysite, cementing marcasite breccia (Nieć, 1968) and chlorite accompanying dolomite and siderite veins were observed (Lögters, 1944; Nieć, 1968) at the iron sulphide deposit at Rudki (Holy Cross Mts., Poland). The replacement of dolomites by clays in this deposit was also supposed but not sufficiently documented (Jaskólski et al., 1953). Dickite associated with $\mathrm{Fe}, \mathrm{Zn}, \mathrm{Pb}$ sulphides and vein carbonates was observed (Chlebowski and Rubinowski, 1970) within the fractured Middle Devonian dolomites at the Holy Cross Mts. near the Łagów village. 


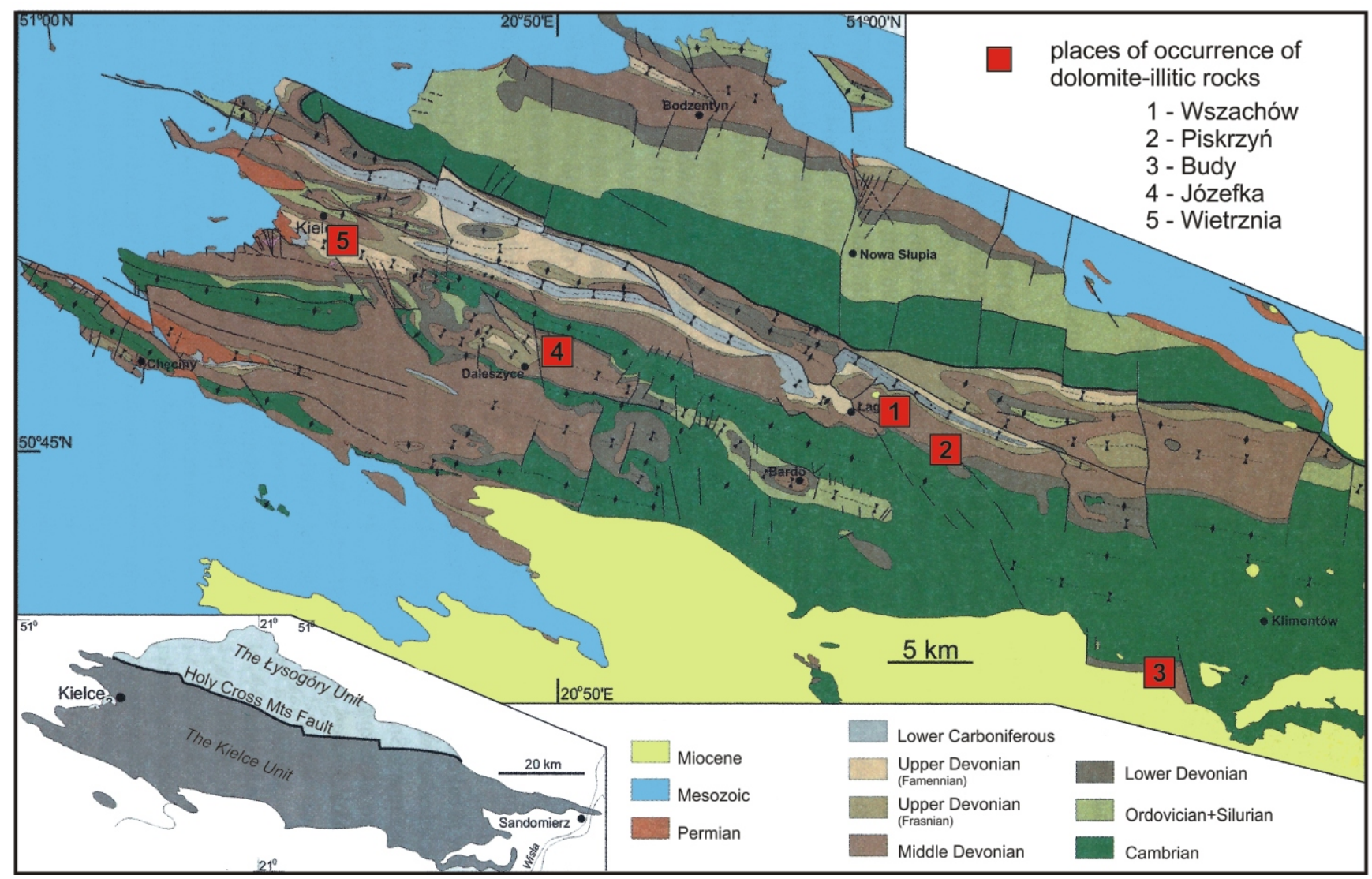

Fig. 1. Location of registered places of occurrence of dolomite-illitic rocks in the Holy Cross Mts. (geological map after Konon, 2006)

Migaszewski $(1990,1991)$ was the first who observed the occurrence of irregular or lenslike bodies of clay accumulation within the Devonian dolomites in the western Holy Cross Mts. and suggested their hydrothermal origin. He also noticed the occurrence of dolomite-clayey rocks and named them "hybrid dolomites" (Migaszewski, 1990). They are grey-greenish or reddish rocks, fine to coarse grained with disseminated fine pyrite. They are composed of euhedral dolomite rhombohedra surrounded by clay minerals. Based on the oxygen isotope study, he has demonstrated hydrothermal origin of such rocks (Migaszewski, 1990), and supposed their formation due to the synsedimentary smockers activity. The nature of clay minerals was not defined.

In the southeastern part of the Holy Cross Mountains similar rocks, composed of dolomite and illite as the main constituents, have been found (Nieć and Pawlikowski, 2015) in three distant active quarries, located in Wszachów, Piskrzyń and Budy (Fig. 1). They accompany iron sulphide-hematite mineralization. The mode of their occurrence suggests that they are the product of recrystallization of dolomite and replacement by illite. Due to the advancement of quarry operations for dolomite, the replacement of dolomite by illite was found widespread. Detailed observation of the mode of occurrence of dolomite-illitic rocks, and their petrographical and geochemical study, presented below, allow discuss their possible origin. The peculiar petrographic features and mineral composition of the dolomite-illitic rocks and their widespread occurrence allow us also to propose colling them "dolillites" instead of previous "hybrid dolomite" applied by Migaszewski (1990). Such rocks observed in various distant sites in the Middle Devonian dolomites, but always within and close to the sulphide-hematite ankerite mineralized fault zones, merit attention as a peculiar accompanying ore wall-rock alteration, and a possible guide to the hidden ore deposits.

\section{STUDY MATERIAL AND METHODS}

The occurrence of dolomite-illitic rocks was observed following quarrying advancement during the past several years in Wszachów, Piskrzyń and Budy (Fig. 1) and allowed sampling for petrographic and geochemical investigations. The basic standard petrographic and ore microscopy study, X-ray diffractometric and chemical analyeis were performed.

The DRON 2.5 diffractometre with monochromatic CuKa radiation was applied in the diffractometric study. The mineral composition was determined with the use of XRYAN program.

Determination of minute mineral inclusions was carried out using a FEI QUANTA 200 FEG scanning electron microscope.

The chemical analysis were performed in the Acme Labs Laboratory (Tables 1-3). About $1 \mathrm{~kg}$ samples were crushed to $2 \mathrm{~mm}$-size grains and, after homogenization; $250 \mathrm{~g}$ were pulverized up to $75 \mu \mathrm{m}$ grain. For the analytical procedure, $0.5 \mathrm{~g}$ was decomposed by lithium borate fusion and aqua regia and then analysed by ICP-ES/MS following the LF 200 and A 200 Acme Labs standard procedures. 
Chemical analysis of samples from Budy Quarry

\begin{tabular}{|c|c|c|c|c|c|c|c|c|c|c|c|c|c|c|}
\hline & & \multicolumn{13}{|c|}{ Samples ${ }^{* *}$} \\
\hline & & 1 & 2 & 3 & 4 & 5 & 6 & 7 & 8 & 9 & 10 & 11 & 12 & 13 \\
\hline $\mathrm{SiO}_{2}$ & \multirow{12}{*}{$\%$} & 1.59 & 3.39 & 17.47 & 4.21 & 4.56 & 6.88 & 7.19 & 11.57 & 20.16 & 31.17 & 10.78 & 1.55 & 11.01 \\
\hline $\mathrm{Al}_{2} \mathrm{O}_{3}$ & & 0.25 & 0.88 & 4.43 & 0.48 & 0.64 & 1.34 & 2.58 & 3.23 & 5.82 & 10.56 & 3.28 & 0.71 & 4.98 \\
\hline $\mathrm{Fe}_{2} \mathrm{O}_{3}{ }^{*}$ & & 0.15 & 0.43 & 2.27 & 0.37 & 0.41 & 0.52 & 1.19 & 1.27 & 2.42 & 2.92 & 1.32 & 20.79 & 45.64 \\
\hline $\mathrm{MgO}$ & & 0.72 & 0.96 & 15.35 & 19.85 & 19.59 & 19.15 & 18.4 & 16.03 & 13.42 & 10.56 & 15.71 & 14.78 & 3.2 \\
\hline $\mathrm{CaO}$ & & 53.52 & 52.37 & 22.23 & 28.58 & 28.43 & 27.33 & 26.59 & 25.9 & 21.59 & 15.02 & 26.05 & 22.92 & 3.79 \\
\hline $\mathrm{Na}_{2} \mathrm{O}$ & & 0.01 & 0.04 & 0.05 & 0.03 & 0.03 & 0.04 & 0.04 & 0.04 & 0.05 & 0.08 & 0.04 & 0.02 & 0.04 \\
\hline $\mathrm{K}_{2} \mathrm{O}$ & & 0.07 & 0.39 & 1.61 & 0.13 & 0.17 & 0.37 & 0.73 & 1.14 & 1.99 & 3.78 & 1.17 & 0.14 & 1.39 \\
\hline $\mathrm{TiO}_{2}$ & & 0.01 & 0.04 & 0.21 & 0.02 & 0.03 & 0.07 & 0.13 & 0.15 & 0.3 & 0.44 & 0.13 & 0.03 & 0.26 \\
\hline $\mathrm{P}_{2} \mathrm{O}_{5}$ & & $<0.01$ & $<0.01$ & 0.05 & $<0.01$ & $<0.01$ & 0.01 & 0.02 & 0.05 & $<0.01$ & 0.12 & $<0.01$ & $<0.01$ & $<0.01$ \\
\hline $\mathrm{MnO}$ & & $<0.01$ & 0.01 & 0.08 & 0.04 & 0.04 & 0.02 & 0.07 & 0.02 & 0.03 & 0.02 & 0.02 & 0.09 & 0.05 \\
\hline $\mathrm{Cr}_{2} \mathrm{O}_{3}$ & & $<0.002$ & $<0.002$ & 0.004 & $<0.002$ & $<0.002$ & 0.002 & 0.003 & 0.003 & 0.006 & 0.009 & 0.004 & $<0.002$ & 0.013 \\
\hline$S$ & & $<0.02$ & 0.36 & 0.03 & $<0.02$ & $<0.02$ & 0.1 & 0.26 & $<0.02$ & $<0.02$ & 0.03 & 0.03 & 0.07 & 35.54 \\
\hline Sc & \multirow{35}{*}{$\mathrm{ppm}$} & $<1$ & $<1$ & 4 & $<1$ & $<1$ & 1 & 2 & 3 & 6 & 10 & 3 & $<1$ & 5 \\
\hline $\mathrm{Ba}$ & & 9 & 23 & 83 & 11 & 11 & 28 & 47 & 47 & 79 & 188 & 52 & 43 & 89 \\
\hline Co & & $<0.2$ & 2.3 & 3.2 & 0.8 & 0.9 & 7.4 & 1.8 & 2.3 & 2.3 & 6.1 & 2.6 & 5.6 & 151.3 \\
\hline Cs & & 0.1 & 0.7 & 2.9 & 0.2 & 0.4 & 0.5 & 1.1 & 2.6 & 4.9 & 7.7 & 2.6 & 0.6 & 3.9 \\
\hline $\mathrm{Ga}$ & & $<0.5$ & $<0.5$ & 5.0 & $<0.5$ & 0.5 & 1.8 & 2.7 & 5.2 & 7.3 & 13.9 & 4.3 & 0.7 & 5.4 \\
\hline $\mathrm{Hf}$ & & $<0.1$ & 0.2 & 1.3 & 0.1 & 0.3 & 0.4 & 0.6 & 0.7 & 2 & 1.7 & 0.5 & $<0.1$ & 1.6 \\
\hline $\mathrm{Nb}$ & & 0.2 & 0.5 & 3.5 & 0.3 & 0.5 & 1.2 & 2.6 & 3 & 5.4 & 8.3 & 2.5 & 0.3 & 4.6 \\
\hline $\mathrm{Rb}$ & & 2.5 & 10.5 & 54.5 & 3.6 & 5 & 10.5 & 20.7 & 44.4 & 80.5 & \begin{tabular}{|l|l|}
140.5 \\
\end{tabular} & 47.5 & 4.4 & 50.7 \\
\hline $\mathrm{Sr}$ & & 215.7 & 334.7 & 99.5 & 78.7 & 77.3 & 93.1 & 88.4 & $\mid 119.1$ & 114.8 & \begin{tabular}{|l|l|}
106.5 \\
\end{tabular} & 128 & 58 & 25.9 \\
\hline Th & & 0.2 & 0.6 & 3.4 & 0.3 & 0.5 & 0.9 & 1.9 & 2.1 & 4.7 & 6.3 & 2 & 0.3 & 3.9 \\
\hline U & & 0.7 & 5.8 & 2.1 & 0.9 & 0.7 & 2.1 & 2.9 & 1.8 & 1.6 & 2.9 & 0.8 & 5.3 & 5.2 \\
\hline V & & $<8$ & 22 & 32 & $<8$ & 8 & 17 & 21 & 26 & 43 & 87 & 22 & 45 & 232 \\
\hline $\mathrm{Zr}$ & & 3.3 & 6.8 & 51.8 & 5.1 & 8.2 & 17.9 & 33.3 & 19.8 & 65.4 & 62.7 & 17.6 & 5.6 & 53.9 \\
\hline Mo & & 0.1 & 2.4 & 0.3 & 0.1 & 0.1 & 5.2 & 0.2 & 0.1 & 0.1 & $<0.1$ & $<0.1$ & 3.5 & 57.9 \\
\hline $\mathrm{Cu}$ & & 0.7 & 8.7 & 2.1 & 0.6 & 0.7 & 4.4 & 1.5 & 3.5 & 1.4 & 4.5 & 1.2 & 1.3 & 381.8 \\
\hline $\mathrm{Pb}$ & & 0.4 & 16.3 & 5.9 & 0.6 & 0.9 & 4.8 & 2.2 & 2.6 & 3.7 & 21.6 & 16.6 & 10.4 & 220.2 \\
\hline $\mathrm{Zn}$ & & 3 & 69 & 47 & 7 & 10 & 4 & 15 & 10 & 11 & 27 & 7 & 649 & 159 \\
\hline $\mathrm{Ni}$ & & 1.3 & 8.1 & 13.2 & 2.6 & 2.7 & 4.5 & 6.5 & 5.1 & 12.5 & 30.7 & 7.5 & 27 & 144.6 \\
\hline As & & $<0.5$ & 13.1 & 10.6 & 0.8 & $<0.5$ & 7 & 4.3 & 4.8 & 5.6 & 6.6 & 1.3 & 106.2 & 195.4 \\
\hline $\mathrm{Se}$ & & $<0.5$ & $<0.5$ & $<0.5$ & $<0.5$ & $<0.5$ & $<0.5$ & $<0.5$ & $<0.5$ & 0.7 & 7.7 & 5.2 & $<0.5$ & 8.4 \\
\hline $\mathrm{Y}$ & & 1.2 & 2.7 & 8.8 & 2.5 & 2.9 & 4.5 & 4.7 & 5.3 & 7.5 & 14.2 & 6.2 & 2.6 & 3.6 \\
\hline La & & 1.5 & 3.4 & 14.0 & 2.5 & 2.6 & 5.4 & 6.3 & 8.2 & 12.5 & 19.8 & 8.5 & 2.6 & 9.6 \\
\hline $\mathrm{Ce}$ & & 1.8 & 7.2 & 29.1 & 5.2 & 5.9 & 10.9 & 13.2 & 17.1 & 23.5 & 43 & 16.7 & 6.2 & 14.3 \\
\hline $\mathrm{Pr}$ & & 0.22 & 0.80 & 3.23 & 0.64 & 0.69 & 1.18 & 1.47 & 1.94 & 2.75 & 5.08 & 1.79 & 0.66 & 1.53 \\
\hline $\mathrm{Nd}$ & & 0.9 & 3.1 & 11.2 & 2.4 & 3 & 4.7 & 5.8 & 6.9 & 9.9 & 19.9 & 6.6 & 2.7 & 5.2 \\
\hline $\mathrm{Sm}$ & & 0.12 & 0.55 & 2.16 & 0.57 & 0.55 & 0.81 & 1.09 & 1.37 & 1.82 & 3.84 & 1.42 & 0.52 & 0.86 \\
\hline $\mathrm{Eu}$ & & 0.04 & 0.12 & 0.43 & 0.11 & 0.12 & 0.19 & 0.2 & 0.3 & 0.43 & 0.77 & 0.27 & 0.12 & 0.14 \\
\hline $\mathrm{Gd}$ & & 0.21 & 0.52 & 1.89 & 0.56 & 0.63 & 1.14 & 1.09 & 1.29 & 1.89 & 3.48 & 1.39 & 0.57 & 0.59 \\
\hline $\mathrm{Tb}$ & & 0.04 & 0.08 & 0.30 & 0.08 & 0.09 & 0.16 & 0.15 & 0.2 & 0.25 & 0.5 & 0.2 & 0.08 & 0.11 \\
\hline Dy & & 0.15 & 0.46 & 1.77 & 0.47 & 0.37 & 0.82 & 0.85 & 1.13 & 1.51 & 2.62 & 1.04 & 0.34 & 0.71 \\
\hline $\mathrm{Ho}$ & & 0.03 & 0.09 & 0.37 & 0.1 & 0.1 & 0.19 & 0.2 & 0.23 & 0.26 & 0.57 & 0.23 & 0.09 & 0.15 \\
\hline $\mathrm{Er}$ & & 0.05 & 0.27 & 0.97 & 0.24 & 0.3 & 0.56 & 0.52 & 0.56 & 0.85 & 1.61 & 0.65 & 0.29 & 0.4 \\
\hline $\mathrm{Tm}$ & & $<0.01$ & 0.04 & 0.14 & 0.03 & 0.04 & 0.07 & 0.1 & 0.09 & 0.13 & 0.23 & 0.09 & 0.04 & 0.07 \\
\hline $\mathrm{Yb}$ & & 0.07 & 0.23 & 0.87 & 0.23 & 0.3 & 0.44 & 0.61 & 0.6 & 0.92 & 1.55 & 0.59 & 0.11 & 0.58 \\
\hline Lu & & $<0.01$ & 0.03 & 0.14 & 0.03 & 0.04 & 0.07 & 0.07 & 0.08 & 0.14 & 0.22 & 0.1 & 0.02 & 0.09 \\
\hline
\end{tabular}

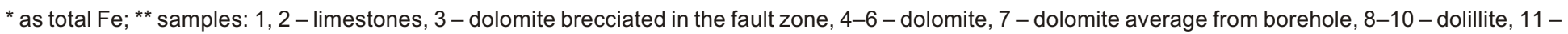
dolillite in the fault zone, 12 - dolomite replaced by hematite, 13 - dolomite replaced by marcasite 
Chemical analysis of samples from Piskrzyń Quarry

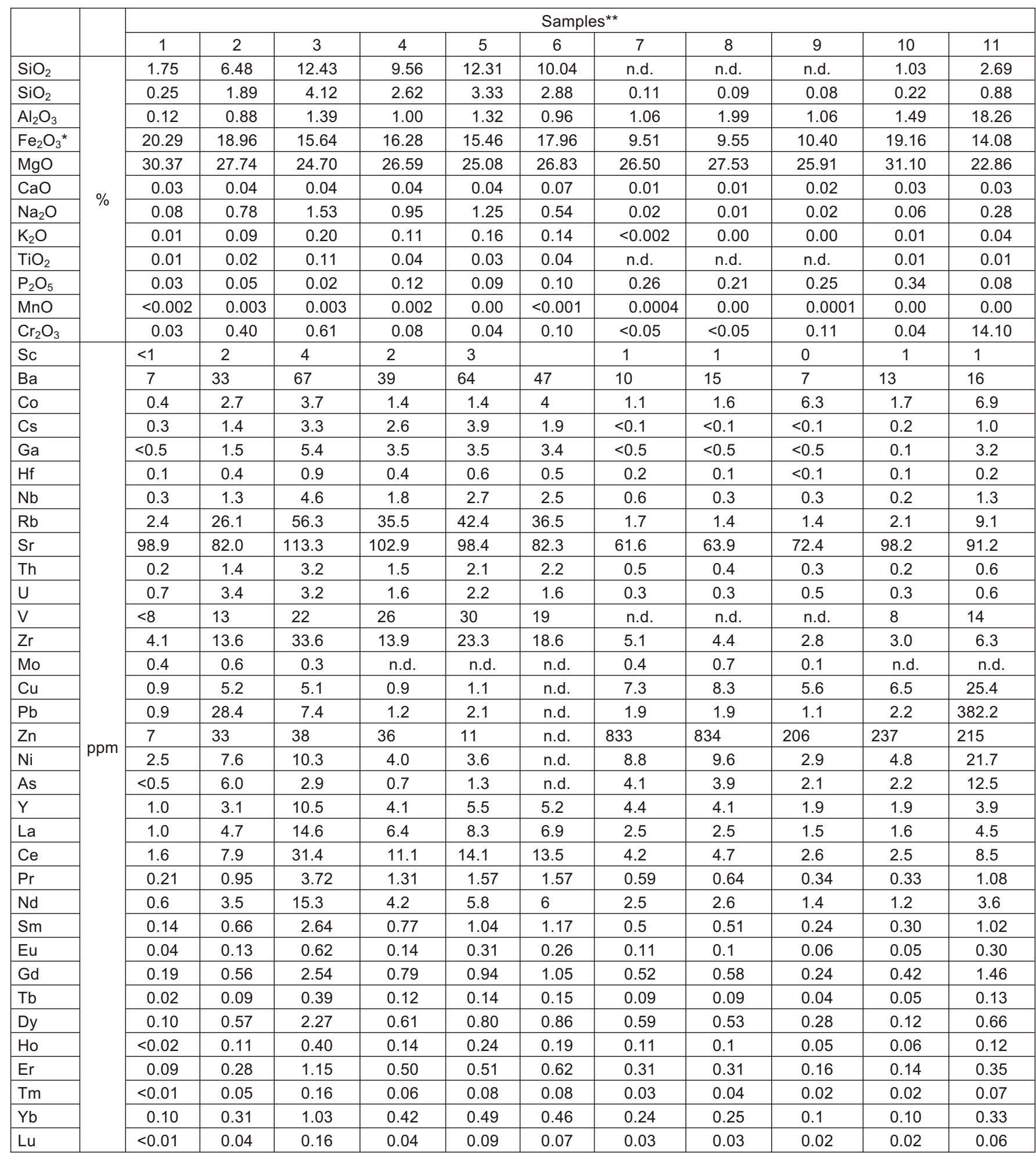

* as total Fe; ** samples: 1 - dolomite, 2-6-dolillite, 7,8-dolomite with limonite veinlets, 9,10 - dolomite impregnated by hematite, 11 - dolomite replaced by marcasite; n.d. - not determined 
Table 3

Chemical analysis of samples from Wszachów Quarry

\begin{tabular}{|c|c|c|c|c|c|c|c|}
\hline & & \multicolumn{6}{|c|}{ Samples** } \\
\hline & & 1 & 2 & 3 & 4 & 5 & 6 \\
\hline $\mathrm{SiO}_{2}$ & \multirow{12}{*}{$\%$} & 0.26 & 2.86 & 6.87 & 9.9 & 19.1 & 44.06 \\
\hline $\mathrm{SiO}_{2}$ & & 0.08 & 0.87 & 1.31 & 2.6 & 4.29 & 13.62 \\
\hline $\mathrm{Al}_{2} \mathrm{O}_{3}$ & & 0.09 & 0.41 & 0.77 & 1.72 & 1.84 & 5.36 \\
\hline $\mathrm{Fe}_{2} \mathrm{O}_{3}{ }^{*}$ & & 20.94 & 19.54 & 17.31 & 13.92 & 14.53 & 6.69 \\
\hline $\mathrm{MgO}$ & & 31.83 & 30.33 & 29.57 & 31.68 & 23.5 & 8.14 \\
\hline $\mathrm{CaO}$ & & 0.02 & 0.03 & 0.03 & 0.03 & 0.05 & 0.08 \\
\hline $\mathrm{Na}_{2} \mathrm{O}$ & & 0.02 & 0.25 & 0.42 & 0.87 & 1.4 & 4.5 \\
\hline $\mathrm{K}_{2} \mathrm{O}$ & & $<0.01$ & 0.04 & 0.07 & 0.13 & 0.19 & 0.59 \\
\hline $\mathrm{TiO}_{2}$ & & $<0.01$ & 0.02 & $<0.01$ & $<0.01$ & 0.01 & 0.19 \\
\hline $\mathrm{P}_{2} \mathrm{O}_{5}$ & & 0.02 & 0.03 & 0.09 & 0.18 & 0.15 & 0.09 \\
\hline $\mathrm{MnO}$ & & $<0.002$ & $<0.002$ & $<0.002$ & 0.003 & 0.004 & 0.012 \\
\hline $\mathrm{Cr}_{2} \mathrm{O}_{3}$ & & $<0.02$ & 0.03 & $<0.05$ & 0.04 & 0.24 & 0.4 \\
\hline $\mathrm{Ba}$ & & 6 & 24 & 43 & 81 & 59 & 200 \\
\hline $\mathrm{Sc}$ & & $<1$ & 1 & 1 & 3 & 4 & 13 \\
\hline Co & & $<0.2$ & 1.4 & 0.8 & 2.6 & 1.2 & 7.3 \\
\hline $\mathrm{Cs}$ & & $<0.1$ & 0.3 & 0.7 & 2.1 & 4.3 & 13.2 \\
\hline $\mathrm{Ga}$ & & $<0.5$ & $<0.5$ & 1.1 & 2.9 & 5.3 & 18.2 \\
\hline $\mathrm{Hf}$ & & 0.1 & 0.3 & 0.3 & 0.8 & 0.9 & 2.5 \\
\hline $\mathrm{Nb}$ & & 0.2 & 0.9 & 1.3 & 2.6 & 4.6 & 12.3 \\
\hline $\mathrm{Rb}$ & & 0.7 & 9 & 13.7 & 32.9 & 58.7 & 175.3 \\
\hline $\mathrm{Sr}$ & & 82.6 & 108.8 & 125.4 & 106.8 & 103.4 & 67.9 \\
\hline Th & & $<0.2$ & 0.7 & 1.1 & 2.1 & 3.1 & 8.9 \\
\hline U & & 1.1 & 1.2 & 1.1 & 0.8 & 2.5 & 7.5 \\
\hline V & & $<8$ & 11 & 16 & 28 & 31 & 95 \\
\hline $\mathrm{Zr}$ & & 4.4 & 9.9 & 11.8 & 29.4 & 41.6 & 90.8 \\
\hline Mo & & 0.2 & 0.5 & $<0.1$ & 0.8 & 0.1 & 0.1 \\
\hline $\mathrm{Cu}$ & & 0.3 & 2 & 1.50 & 10 & 1 & 2.9 \\
\hline $\mathrm{Pb}$ & & 0.6 & 4.3 & 1.10 & 3.2 & 3 & 92.2 \\
\hline $\mathrm{Zn}$ & & 7 & 17 & 20.00 & 45 & 22 & 17 \\
\hline $\mathrm{Ni}$ & ppm & 2.1 & 4 & 3.00 & 10.7 & 5.9 & 17.4 \\
\hline As & & $<0.5$ & 2.1 & 1.30 & 6.5 & 0.6 & 0.6 \\
\hline $\mathrm{Se}$ & & $<0.5$ & $<0.5$ & $<0.5$ & $<0.5$ & $<0.5$ & 27.6 \\
\hline$Y$ & & 1.1 & 3.5 & 3.0 & 6.2 & 3.9 & 12.1 \\
\hline La & & 0.8 & 4 & 3.8 & 7.8 & 8.1 & 24.3 \\
\hline $\mathrm{Ce}$ & & 1.1 & 6.5 & 7.5 & 14 & 12.6 & 44.8 \\
\hline $\mathrm{Pr}$ & & 0.13 & 0.79 & 0.87 & 1.6 & 1.39 & 5.11 \\
\hline $\mathrm{Nd}$ & & 0.6 & 2.9 & 3.3 & 5.7 & 4.7 & 18.5 \\
\hline $\mathrm{Sm}$ & & 0.12 & 0.58 & 0.61 & 1.14 & 0.84 & 3.4 \\
\hline $\mathrm{Eu}$ & & 0.02 & 0.12 & 0.12 & 0.22 & 0.16 & 0.66 \\
\hline $\mathrm{Gd}$ & & 0.14 & 0.59 & 0.62 & 1.14 & 0.82 & 2.95 \\
\hline $\mathrm{Tb}$ & & 0.02 & 0.09 & 0.09 & 0.17 & 0.12 & 0.43 \\
\hline Dy & & 0.15 & 0.56 & 0.52 & 1.08 & 0.73 & 2.25 \\
\hline $\mathrm{Ho}$ & & 0.03 & 0.11 & 0.11 & 0.23 & 0.15 & 0.46 \\
\hline $\mathrm{Er}$ & & 0.08 & 0.31 & 0.29 & 0.62 & 0.5 & 1.32 \\
\hline $\mathrm{Tm}$ & & $<0.01$ & 0.04 & 0.04 & 0.08 & 0.08 & 0.19 \\
\hline $\mathrm{Yb}$ & & 0.08 & 0.3 & 0.25 & 0.56 & 0.46 & 1.33 \\
\hline $\mathrm{Lu}$ & & $<0.01$ & 0.04 & 0.03 & 0.08 & 0.07 & 0.2 \\
\hline
\end{tabular}

* as total Fe; ${ }^{* *}$ samples: 1 - dolomite, Upper Givetian, 2 - dolomite, Eifelian (average crushed stone), 3 - weathered dolillite, 4, 5 - dolillite, 6 - illite vein 


\section{GEOLOGICAL SETTING OF DOLOMITE-ILLITIC ROCKS}

The Holy Cross Mountains are located in central Poland. They are the inlier of folded Paleozoic rocks emerging from surrounding Permian. Mesozoic and Cenozoic deposits (Fig. 1). The oldest Cambrian to Ordovician predominantly terrigenous rocks are unconformably covered by Lower Devonian siliciclastics (mostly quarzitic sandstones and shales) and Middle to Upper Devonian and Lower Carboniferous carbonates (dolomites, limestones and marls). The phenomenon of the replacement of dolomite by illite was encountered in Middle and Upper Devonian dolomites in the southern part of the Holy Cross Mts. called the Kielce Unit (Fig. 1). Detailed studies were carried out in the Wszachów, Piskrzyń and Budy quarries, located in the southeastern part of the Holy Cross Mts. (Fig. 1), near the great $\mathrm{N}-\mathrm{S}$-oriented transversal strike-slip faults dissecting the Paleozoic massif.

The Wszachów Quarry is situated in the eastern part of the Kielce-Łagów synclinorium (northern part of the Kielce Unit), on the southern limb of the Łagów Syncline. It is located within the Eifeilan, finely bedded, predominantly micritic dolomites, and partly within the NE-SW-trending fault zone (Walczowski, 1968), which separate them from fine crystalline fossiliferous Givetian dolomites, appearing to the east of the fault. The fault zone, about 10-20 m wide is filled by irregular rotated blocks of brecciated dolomites and dolomite-illitic rocks, partly ankeritic and dedolomitized due to weathering near the ground surface. The dolomite-illitic rocks are finely to medium-crystalline, with green illite aggregates up to a few $\mathrm{mm}$ in size, of irregular shape and distribution (Fig. 2). Both dolomite and ankeritic dolomites are dissected by numerous variously oriented veinlets of crystalline dolomite, anketrite, dolomite-silica and illite-dolomite. Their thickness varies from few millimetres up to locally $20 \mathrm{~mm}$. The irregular vein-shaped illite accumulation appears between the blocks of dolomite illitic rocks. Within the exposed weathered fault breccia some nests of boxwork limonite and hematite suggest the existence of iron sulphides, which appears at deeper levels of the quarry.

The Piskrzyń Quarry is also situated in the eastern part of the Kielce-Łagów synclinorium, on the southern limb of the Łagów Syncline close to the N-S-trending fault zone located eastward (Dowgiałło, 1974; Antoniuk et al., 2005). It is situated within the Givetian finely to medium-crystalline dolomites, locally fossiliferous, with small coral bioherms. They are intensively folded and faulted in front of a NWW-SEE-trending flexure. Locally marcasite-pyrite and hematite mineralization appears here in the fractured and brecciated rocks, and limonite-stained rocks are present near the surface (Nieć and Pawlikowski, 2015).

The grey dolomites are irregularly, spotty transformed to rose-greenish rock varieties. The bedding vanishes partly and the conchoidal parting of rock fragments becomes characteristic. Illite replacing dolomite is the main constituent of such rose-greenish rocks.

The Budy Quarry is situated on the southern slope of the Klimontów anticlinorium formed by folded predominantly Cambrian rocks (Fig. 1), near the transversal N-S-trending fault zone occurring eastward (Romanek, 1977). It is located within the Givetian limestones irregularly transformed to dolomites, which predominate in the accessible part of the quarry. The dolomitization is epigenetic (Narkiewicz, 1991, 2009). Limestones occur here within the dolomites as isolated irregular metric-sized relic bodies. The entire rock series is cut by NWW-SEE and NNE-SSW faults, with the prominent strike-slip component, and by accompanying smaller feather faults. In the fault zones there are marcasite-pyrite and hematite veinlets, irregular centimetric-sized accumulations and impregnations. The most prominent is the NWW-SEE fault zone oblique to the longitudinal quarry axis. It is about $10 \mathrm{~m}$ wide. Within it, dolomites are intensively fractured and brecciated. The dolomite breccia is cemented predominantly by illite, with some dispersed hematite admixture and angular fragments of finely crushed dolomite. Dolomite-illitic rocks appear in the sidewalls of faults and close to the marcasite-pyrite-hematite mineralization sites. Limonite occurs near the surface as a product of oxidation of iron sulphides, that are present below at a depth of about $40 \mathrm{~m}$.

Dolomites which are transformed to dolomite illitic rocks in a similar way as in the Piskrzyń, Budy and Wszachów quarries were formerly observed by Migaszewski (1990) in the Wietrznia and Józefka quarries in the western part of the Holy Cross Mts. (Fig. 1), within the Upper Devonian (Fransian) dolomitized limestones. That in the Józefka Quarry is the most interesting.
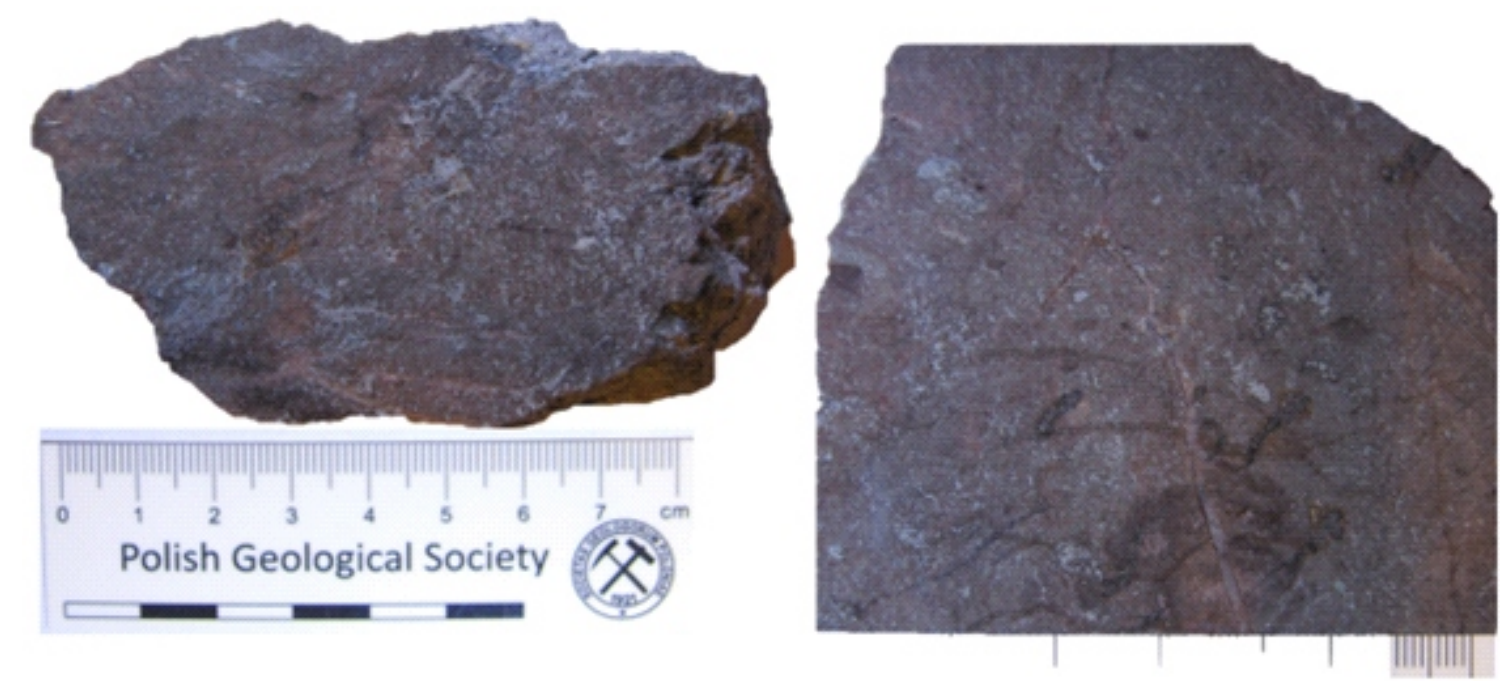

Fig. 2. Irregular aggregates of illite (green spots) in dolomite Wszachów Quarry 


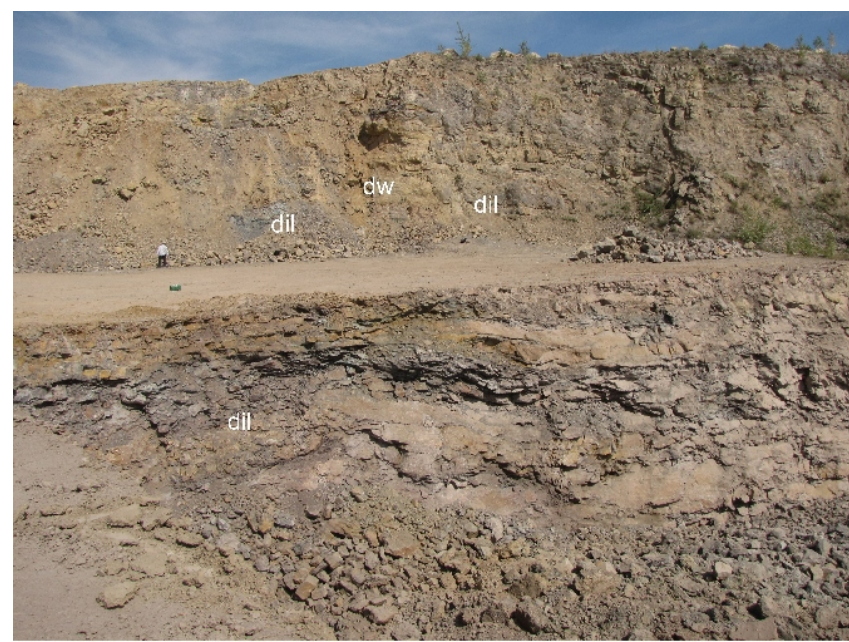

Fig. 3. Irregular spotted presence of dolomite-illitic rocks (greenish) at the NWW-SEE fault zone, Budy Quarry

dil - dolomite-illitic rocks, dw - limestones replaced by dolomite

There, the dark grey micritic limestones in the sidewall of the fault are completely replaced by coarse-crystalline "saccharoïdal", creamy white, finely to medium-crystalline dolomite and greenish-red iron sulphide and hematite impregnating dolomite-illitic rocks. Such rocks were also recently noticed within tectonically disturbed rock sequences in other dolomite quarries between Wietrznia and Józefka.

\section{DOLOMITE-ILLITIC ROCKS (DOLILLITES)}

\section{MODE OF OCCURRENCE AND PETROGRAPHIC FEATURES}

Dolomite-illitic rocks are distinguishable by their greenish or greenish-rose colour or greenish irregular staining. They are massive homogeneous and fine-grained. The conchoidal

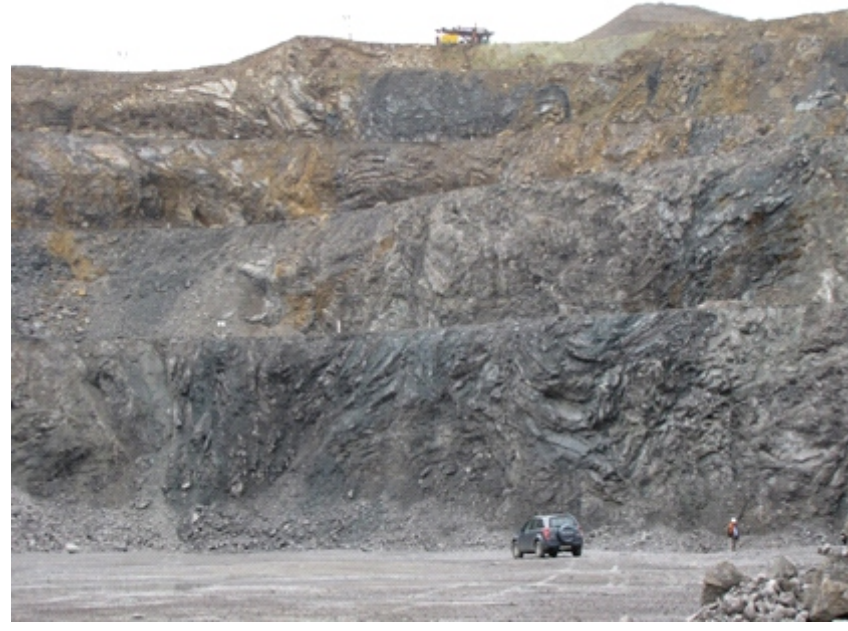

Fig. 4. Spotted occurrence of dolomite-illitic rocks (greenish) within the folded and faulted Middle Devonian dolomites, Piskrzyń Quarry, mining level IV north

shape of the broken surface is their peculiar feature. They appear irregularly within the tectonically disturbed dolomites (Figs. 3 and 4), close to the faults or within the fault breccia (Figs. 5 and 6). They form variously shaped nests, lens-like or vein-shaped bodies, with blurred, or less commonly sharp boundaries subordinated to the bedding planes or fracture walls (Figs. 7-9). In some places illite with dolomite or hematite admixture form veins, ten to twenty millimetre thick, filling fractures (Fig. 10). The mode of occurrence of dolomite-illitic rocks is clearly epigenetic to the host, unaltered, grey dolomites.

The transition from dolomite to dolomite-illitic rock is most often gradual. It starts from microsparitic, partly recrystallized grey dolomite with dispersed neo-formed dolomite rhombohedra or irregular saddle dolomite aggregates with illitic matrix appearing in the interstitial space (Fig. 11). The increase in illite content results in the formation of irregular greenish milimetric

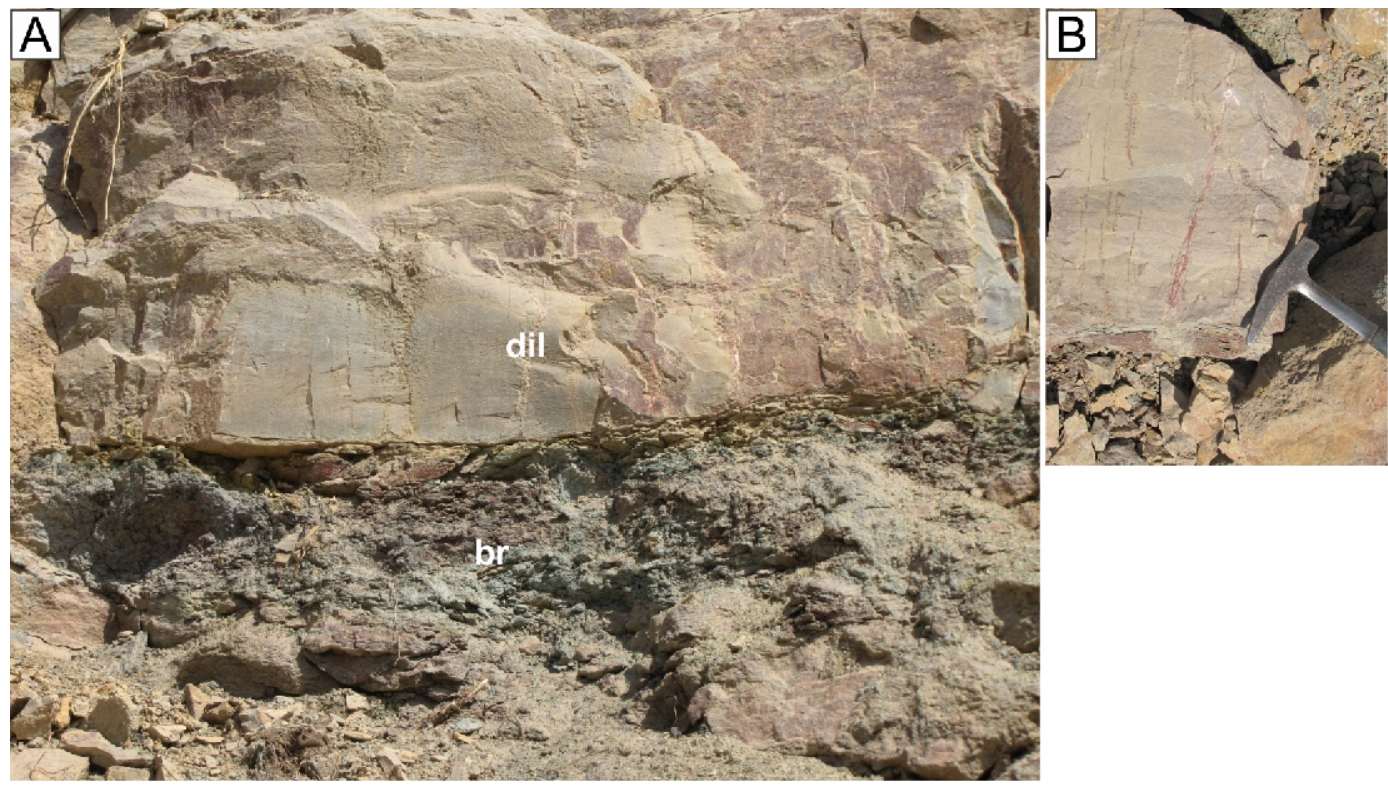

Fig. 5. Illitic dolomite, Budy Quarry, mining level II, north wall

A - dolomite-illitic rock in layers (dil) and breccia (br), B - hematite veinlets in dolomite-illitic rock 


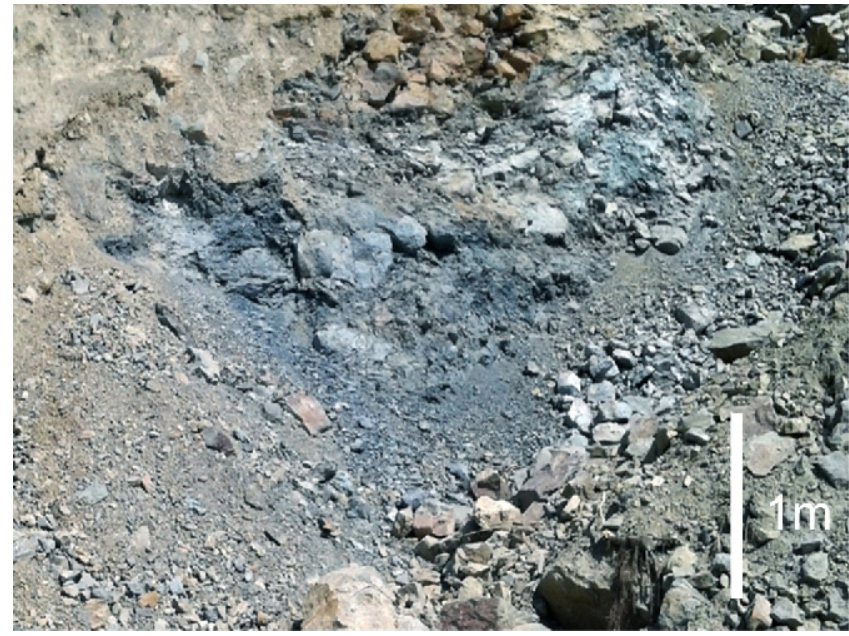

Fig. 6. Nestlike occurrence of dolomite-illitic rocks (green) in brecciated dolomite, Piskrzyn Quarry, level II

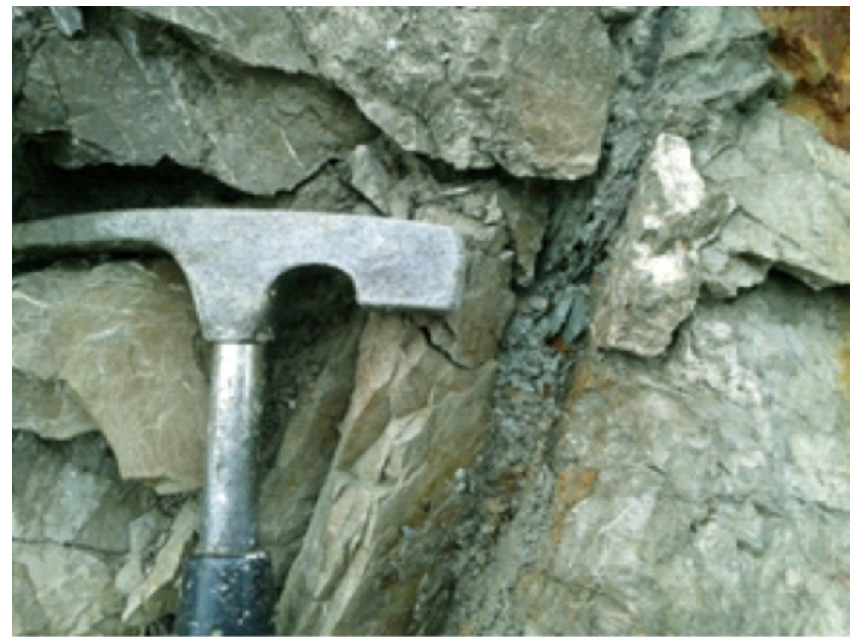

Fig. 7. Illite vein in dolomite, Budy Quarry, level V

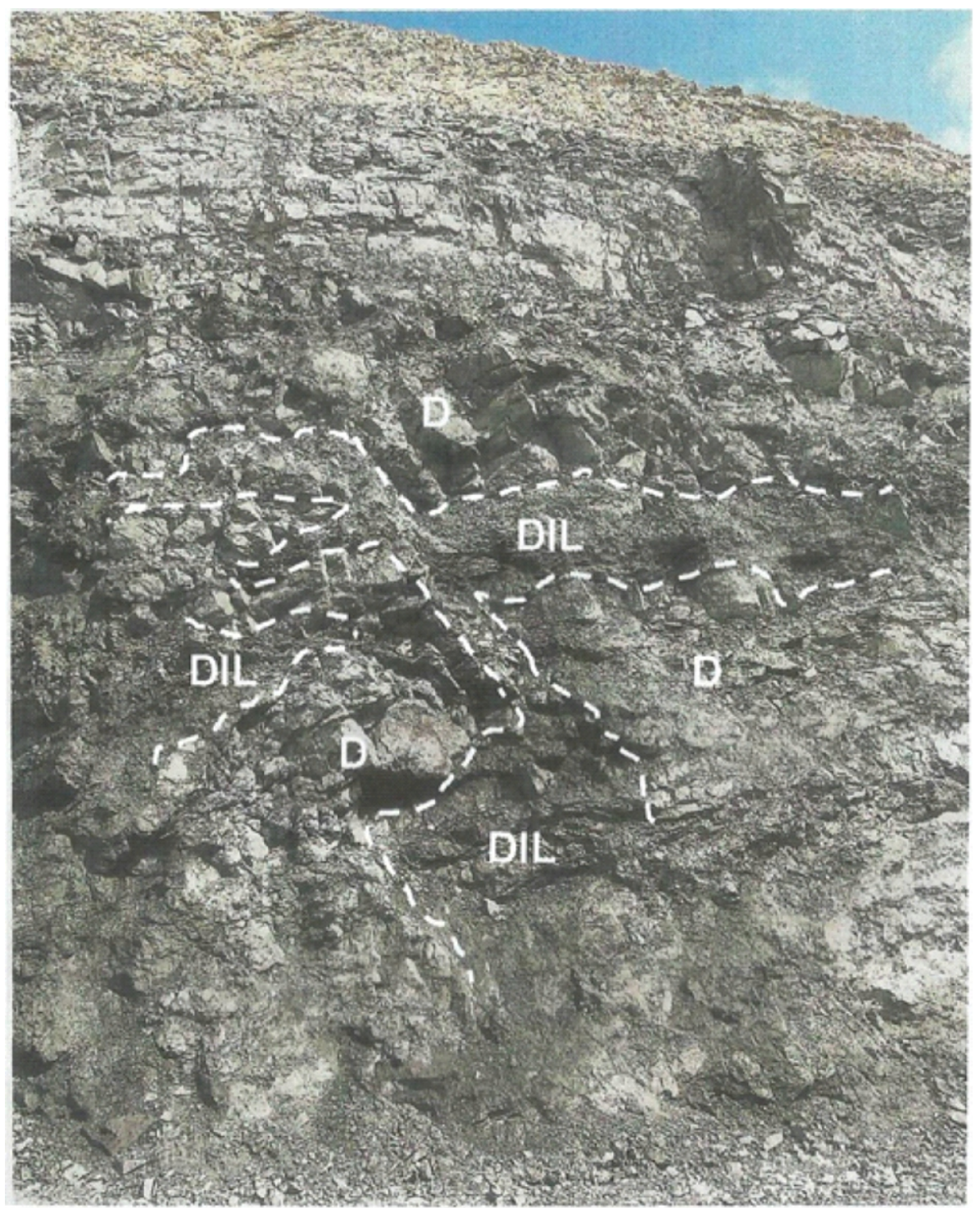

Fig. 8. Irregular occurrence of dolomite- illitic rocks replacing dolomites, Piskrzyń Quarry, mining level III, the quarry wall is $10 \mathrm{~m}$ high 

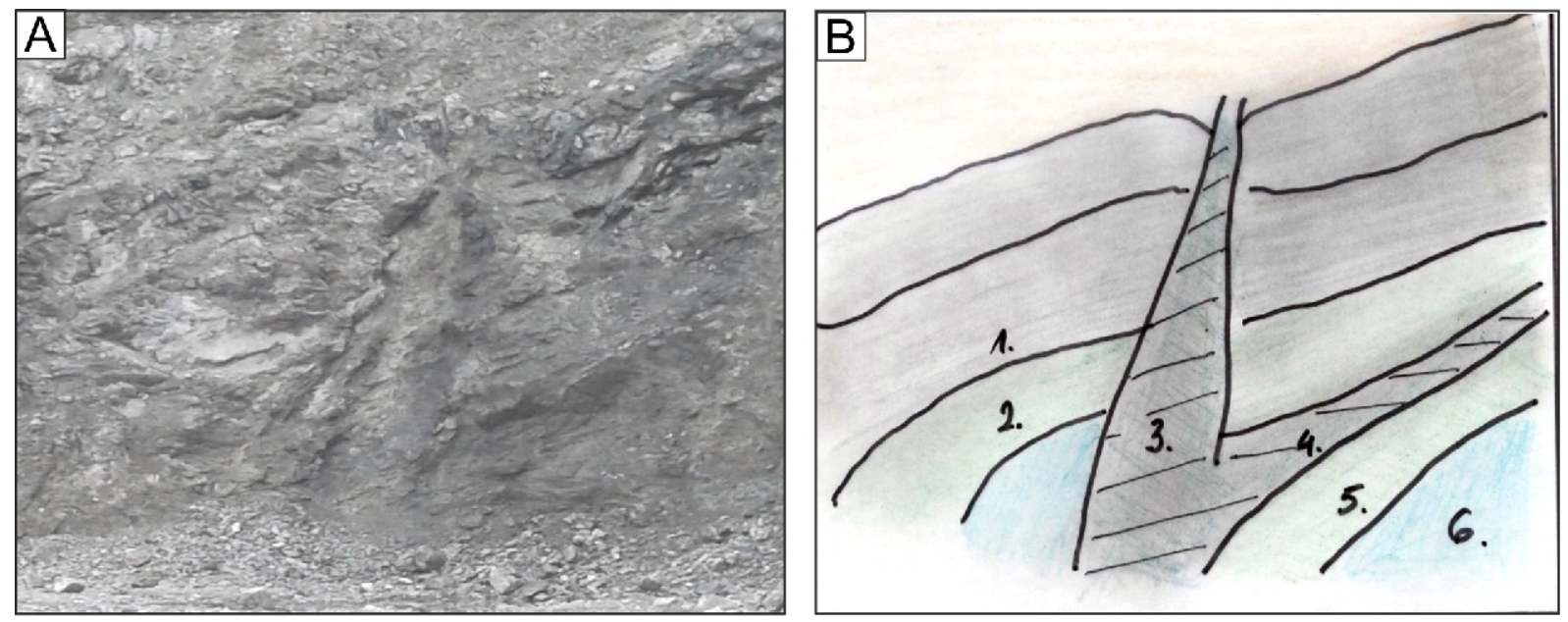

Fig. 9. Dolomite-illite veins in the non-transformed dolomite (A), Piskrzyń Quarry, level IV, eastern wall; $B$ - dolomite layers $(1,2,5,6)$, dolomite-illitic rock $(3,4)$

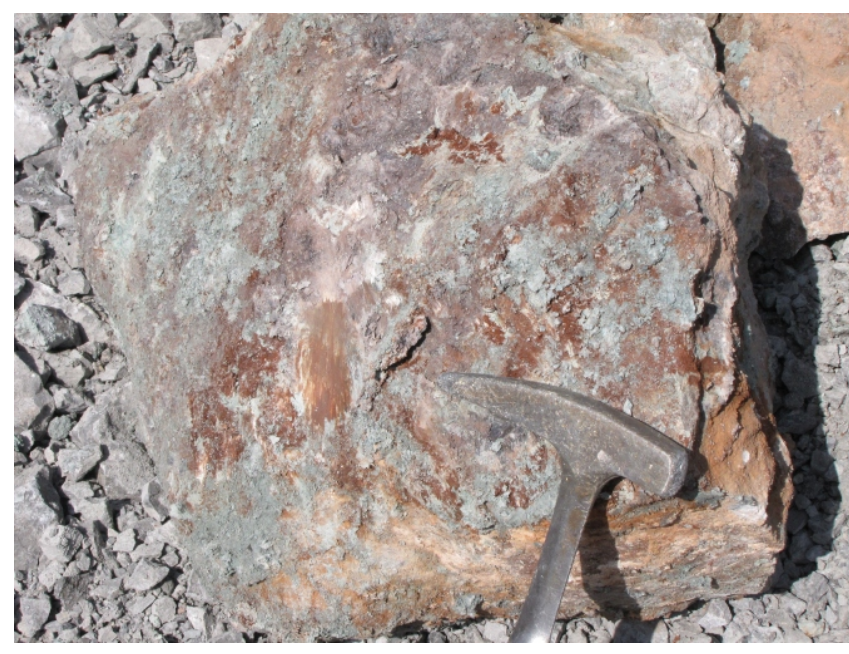

Fig. 10. Illite-hematite vein fillling, Budy Quarry, level V

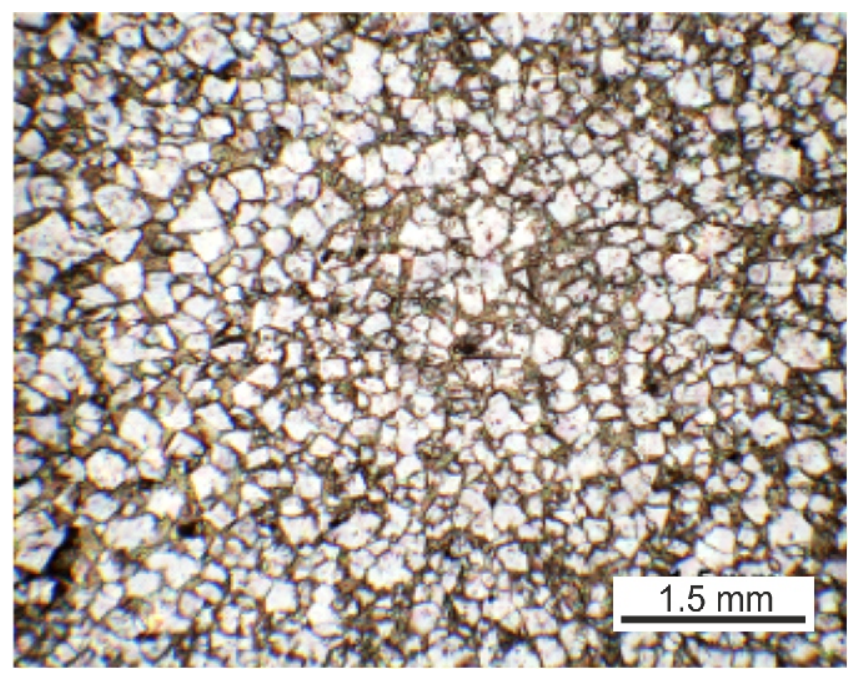

Fig. 11. Microstructure of dolomite-illitic rock (dolillite), transmitted cross-polarized light

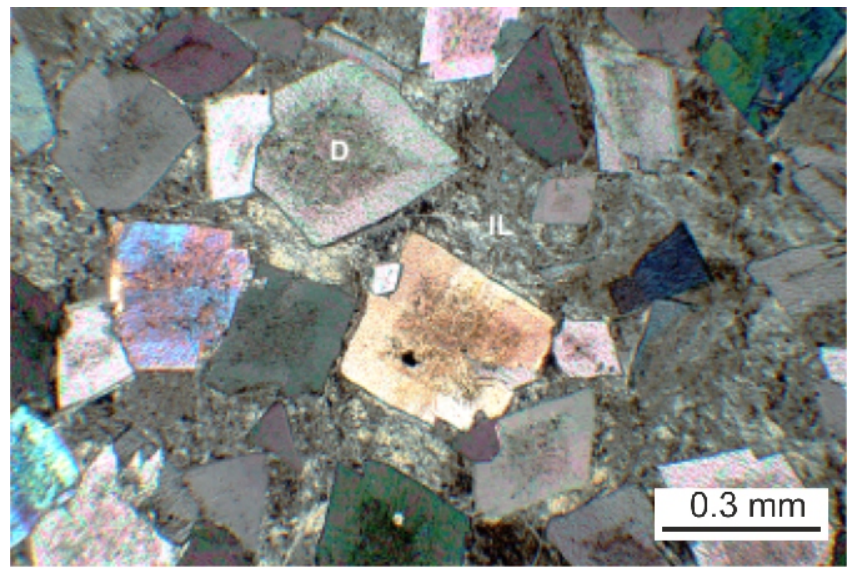

Fig. 12. Microstructure of dolomite-illitic rock (dolillite), transmitted cross-polarized light

$$
\text { D - dolomite, IL - illite }
$$

to centimetric-sized spots dispersed within grey (or brownish if weathered) host dolomites (Fig. 2). The final stage of the process of dolomite replacement by illite is the formation of greenish-rose, predominantly illitic rocks with scattered dolomite rhombohedra (Fig. 12). The greenish-rose colour intensity more or less corresponds to the degree of rock transformation. Some silica admixture, hardly visible microscopically, accompanies the illite. The predominant silica replacement of dolomite is present locally. The dolomite-illitic rocks, as well as the surrounding unaltered dolomites, contain minute iron sulphide or hematite impregnation, and their dispersed irregular, milimetric-sized, shapeless aggregates, streaks or discontinuous veinlets. In places iron sulphides or siderite form tiny partial coating on dolomite grains. Iron sulphides predominates in the greenish rock varieties, whereas hematite occurrence is marked by the rose colouration of rock. The $X$ ray analysis reveal the clear presence of silica admixture (Figs. 13 and 14).

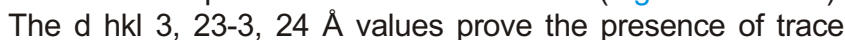
amounts of K-feldspar.

The dolomite rhombohedra that occurs within illitic rock matrix often show complex structure. Their central parts are micritic with minute iron sulphide impregnation, surrounded by 


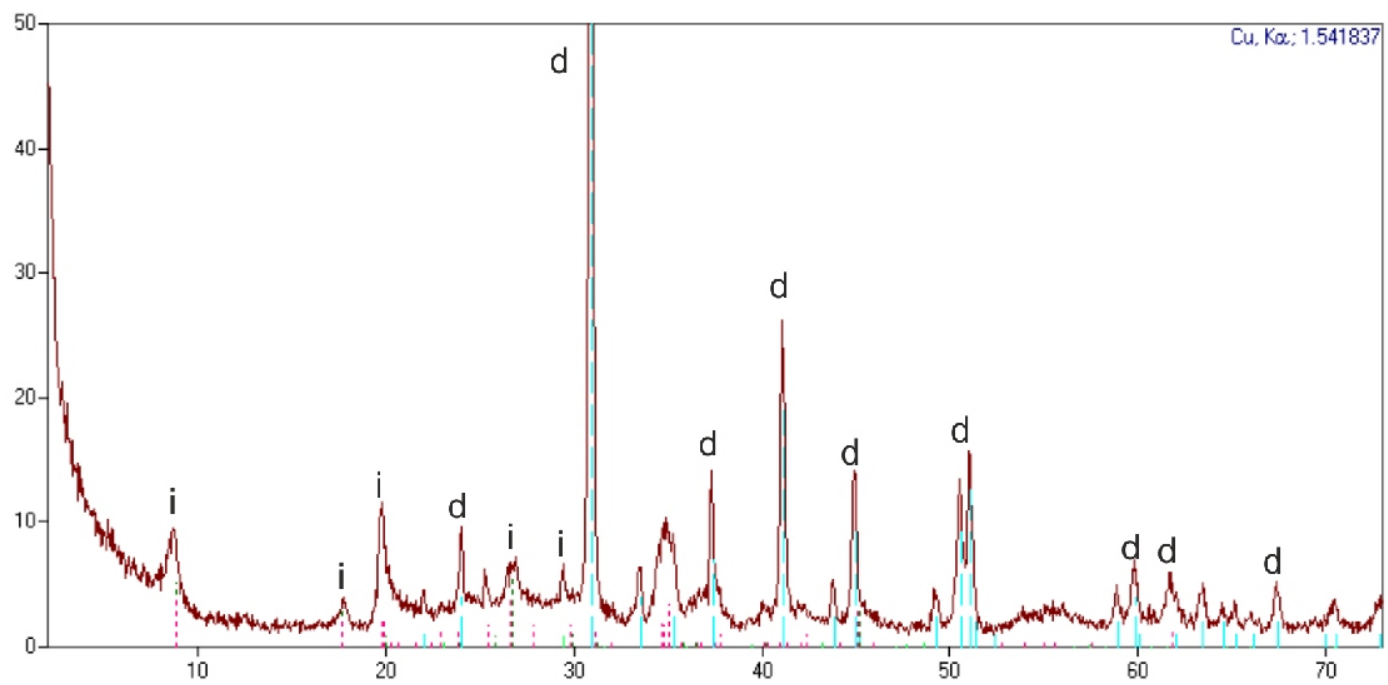

Fig. 13. X-ray patterns of dolomite-illitic rock from the Budy Quarry

$$
\text { d-dolomite, i - illite }
$$

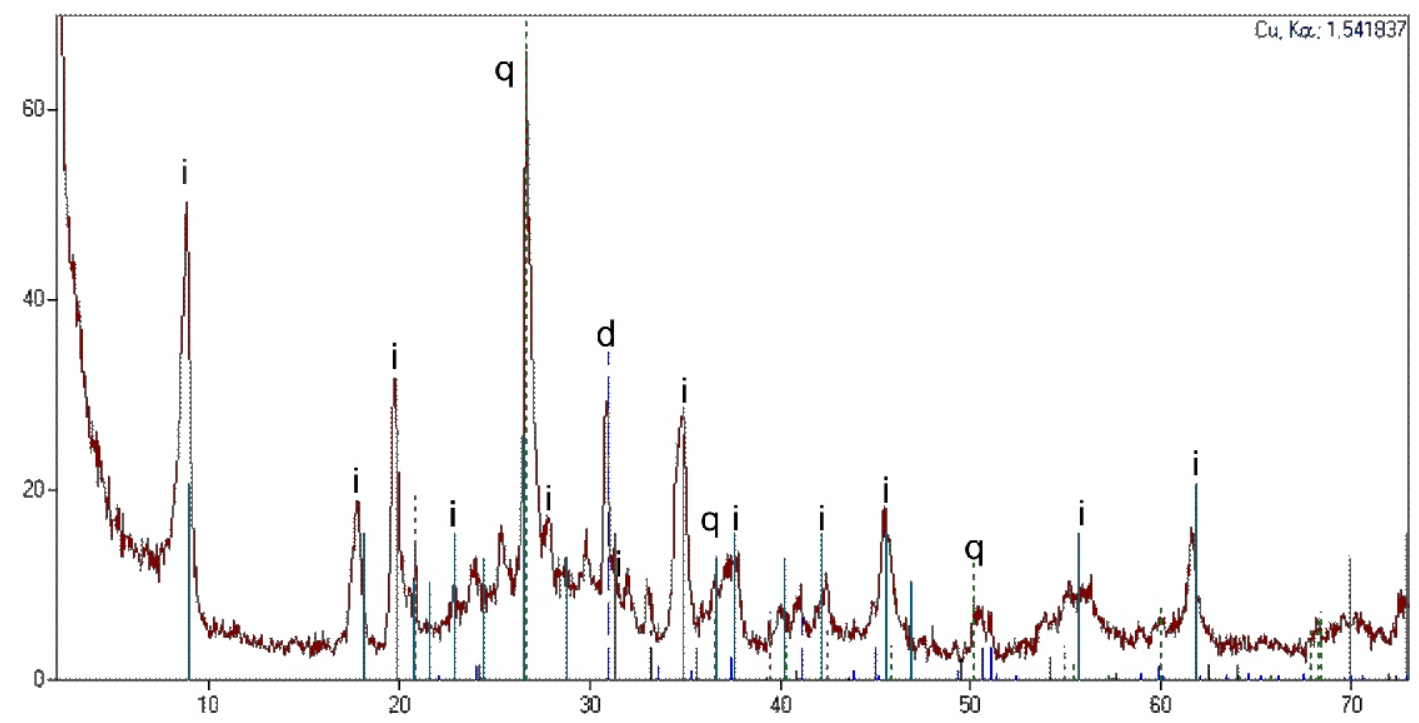

Fig. 14. X-ray patterns of dolomite-illitic rock from Piskrzyń Quarry

$q$ - quartz, other explanations as in Figure 13

monocrystalline dolomite coatings (Fig. 12). Some dolomite crystals are corroded by illite (Fig.15).

Within the massive vein-like accumulations, illite is accompanied by disseminated, X-ray detectable silica, and contain disseminated iron sulphide, as well scattered dolomite grains. Some of them reveals a sferolitic structure or has a siderite coating (Fig. 16). Within the illite aggregates, disseminated micrometric-sized euhedral pyrite crystals are present, as evidenced from SEM-RDS data (Figs. 17-19).

Illite replacing dolomite is well crystallized, $2 \mathrm{M} 1$ type. Kübler crystallinity index close to $0.70 \Delta 2 \theta$, and lack of detectable smectite suggests that it crystallized at the temperature ranging from about $150^{\circ} \mathrm{C}$ may be up to $250^{\circ} \mathrm{C}$ (Yates and Rosenberg, 1998; Junfeng and Brown, 2000). It is macroscopically characterized by a green colour of varied intensity and locally with a bluish tint, most probably due to the presence of chromium in the crystal lattice, as evidenced by the $\mathrm{Cr}_{2} \mathrm{O}_{3}$ content correlated with $\mathrm{K}_{2} \mathrm{O}$ (Fig. 20).

The presented mode of occurrence, and petrographic features of dolomite-illitic rocks demonstrate, their hydrothermal origin through recrystallization of dolomite host rock and replacement by illite. The unaltered dolomites as well as locally dolomite-illitic rocks are cut by carbonate veins, whose coarsely crystalline saddle dolomite is the most prominent component.

\section{GEOCHEMICAL FEATURES}

Dolomite-illitic rocks are obviously enriched in $\mathrm{Si}, \mathrm{Al}$ and $\mathrm{K}$, as well $\mathrm{Fe}$ and $\mathrm{S}$ due to the dispersed iron sulphides. The elevated $\mathrm{Rb}$ content, up to $100 \mathrm{ppm}, 10$ times greater than in unaltered dolomite, following the increased $\mathrm{K}_{2} \mathrm{O}$ content (Fig. 21) is explained by potassium substitution by $\mathrm{Rb}$. Their relationship 

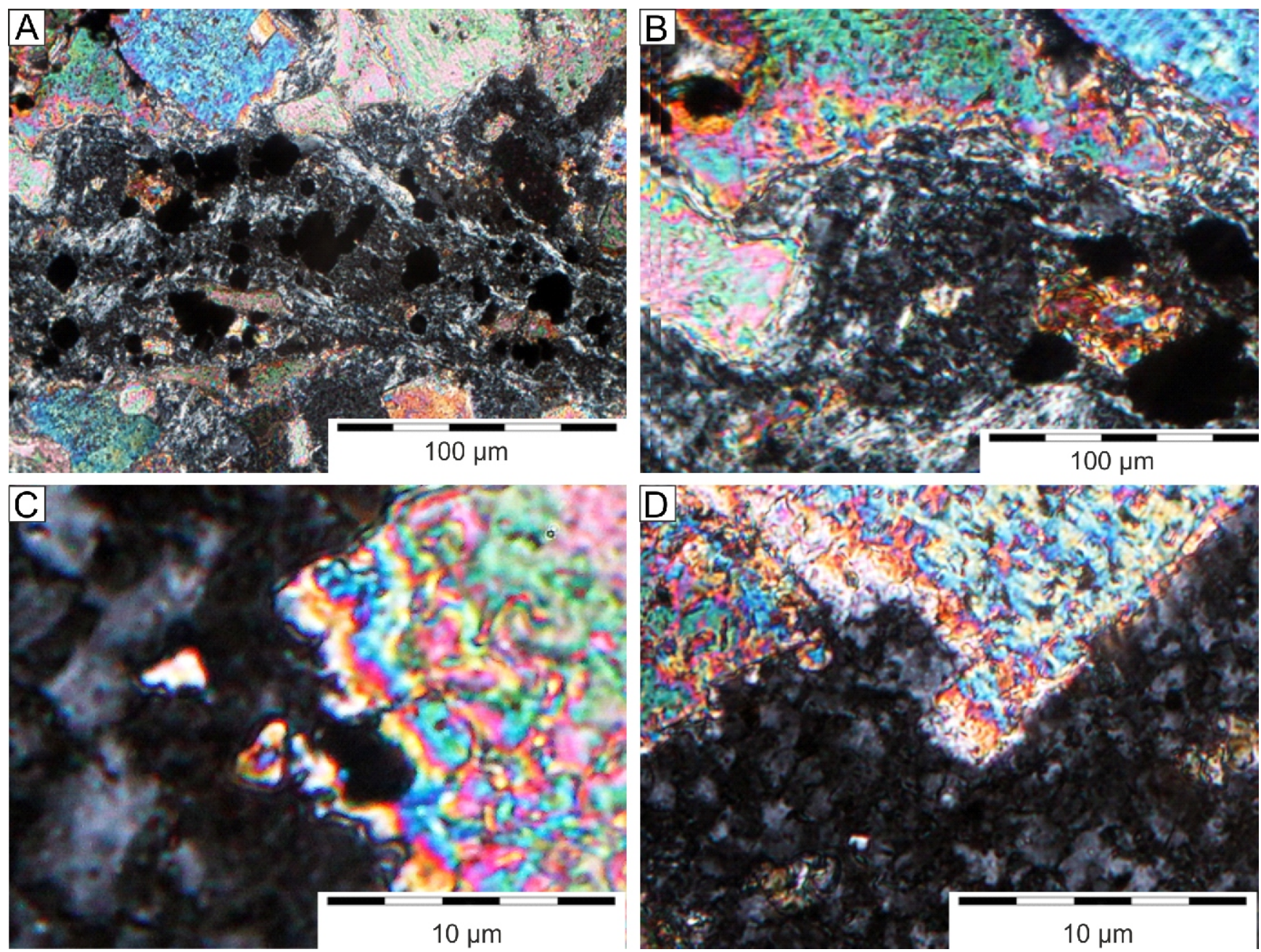

Fig. 15A - illite vein with sulphides in dolomite replaced by illite; B - illite aggregate with sulphides in dolillite; C, D - corroded dolomite crystals at the boundary with illite, transmitted cross-polarized light

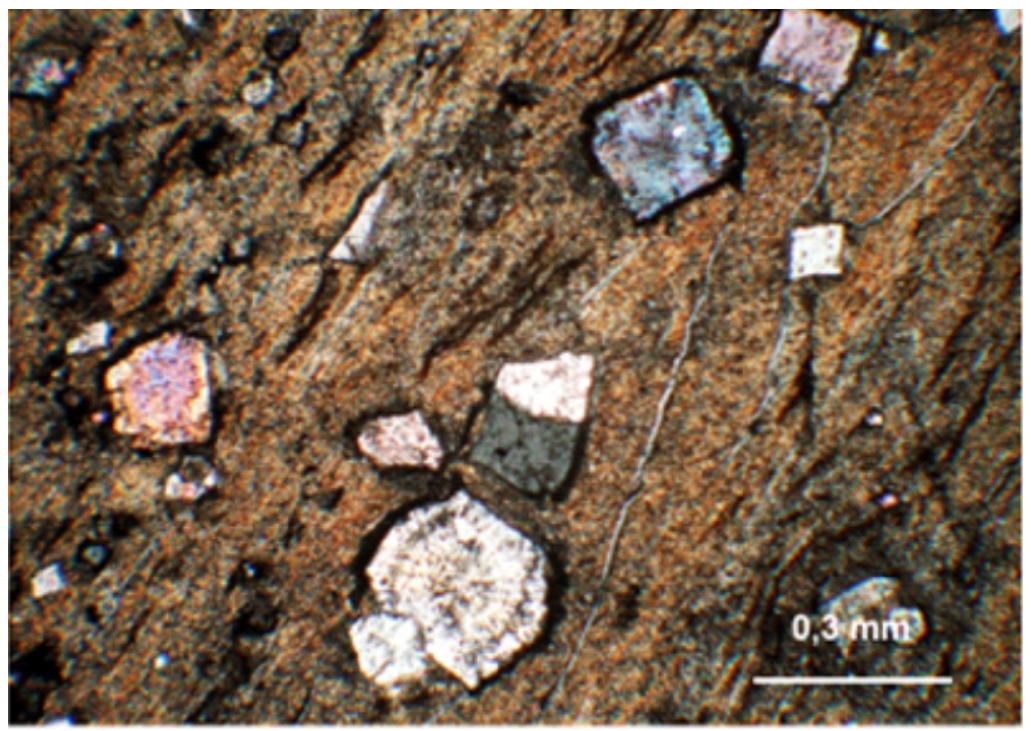

Fig. 16. Scattered dolomite grains with a siderite rim within the illite vein, transmitted cross-polarized light 


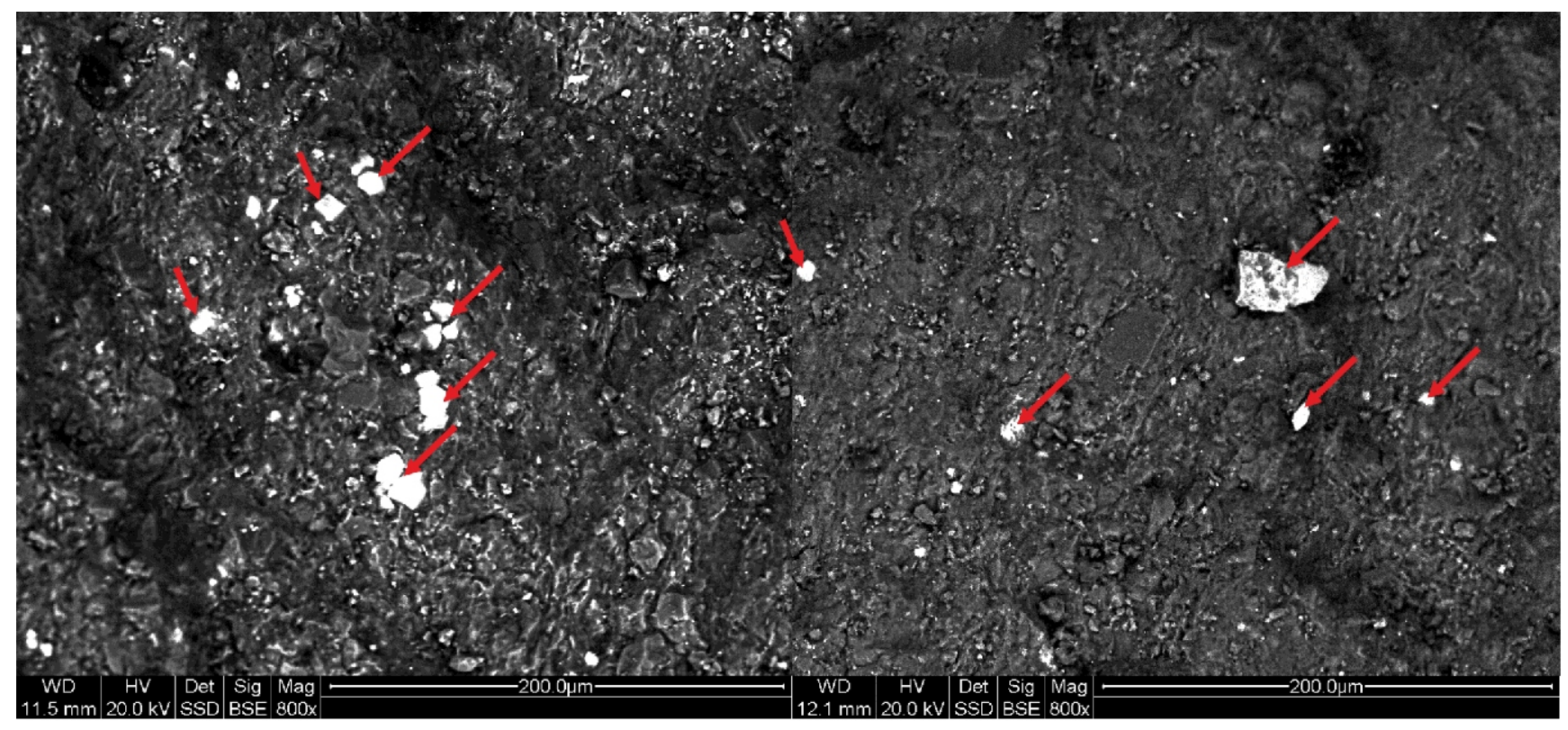

Fig. 17. Pyrite microcrysts in illite

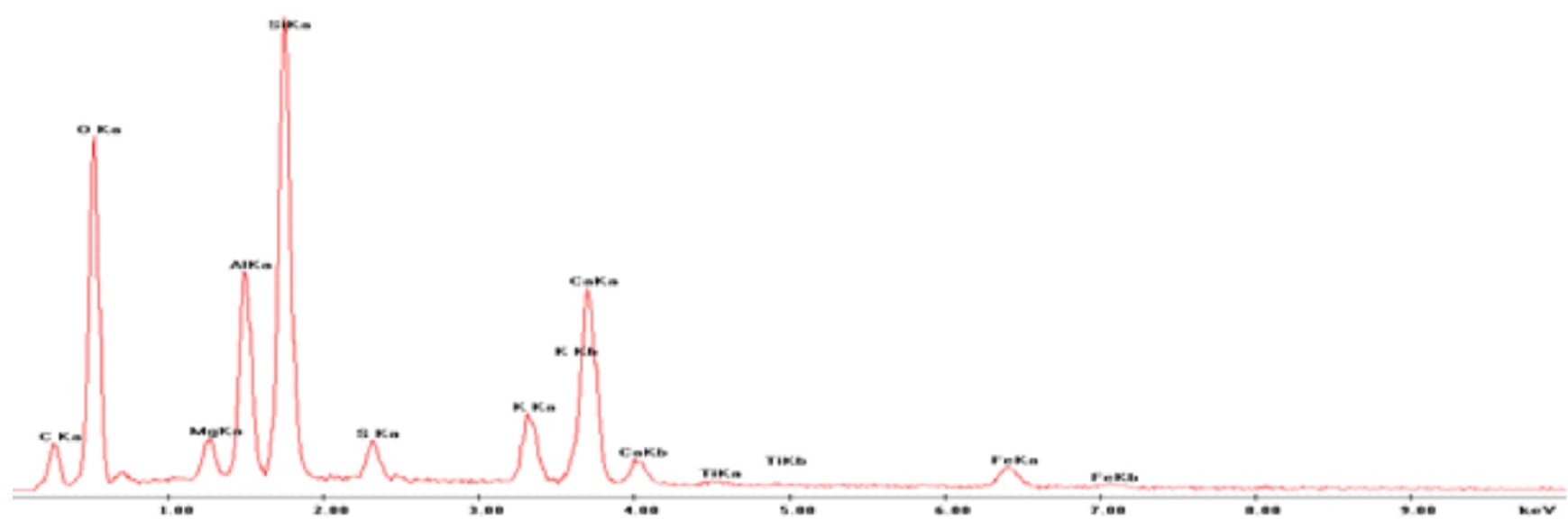

Fig. 18. EDS of illite with pyrite (see Fig. 16)

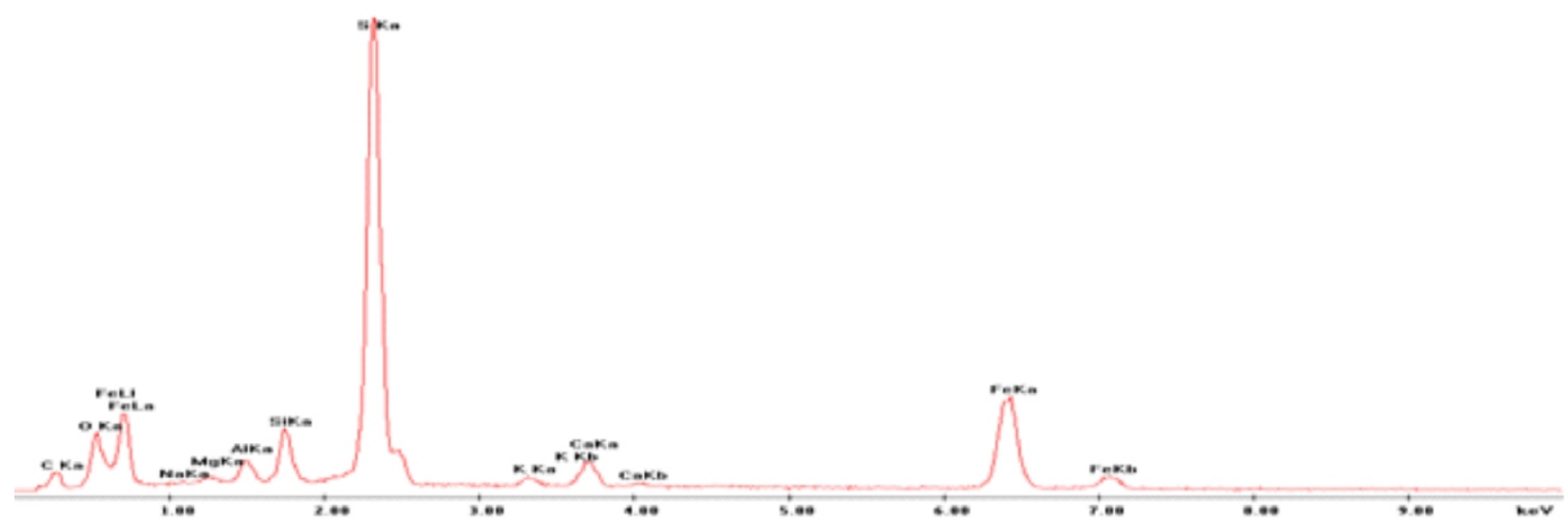

Fig. 19. EDS of pure pyrite present in Figure 16 


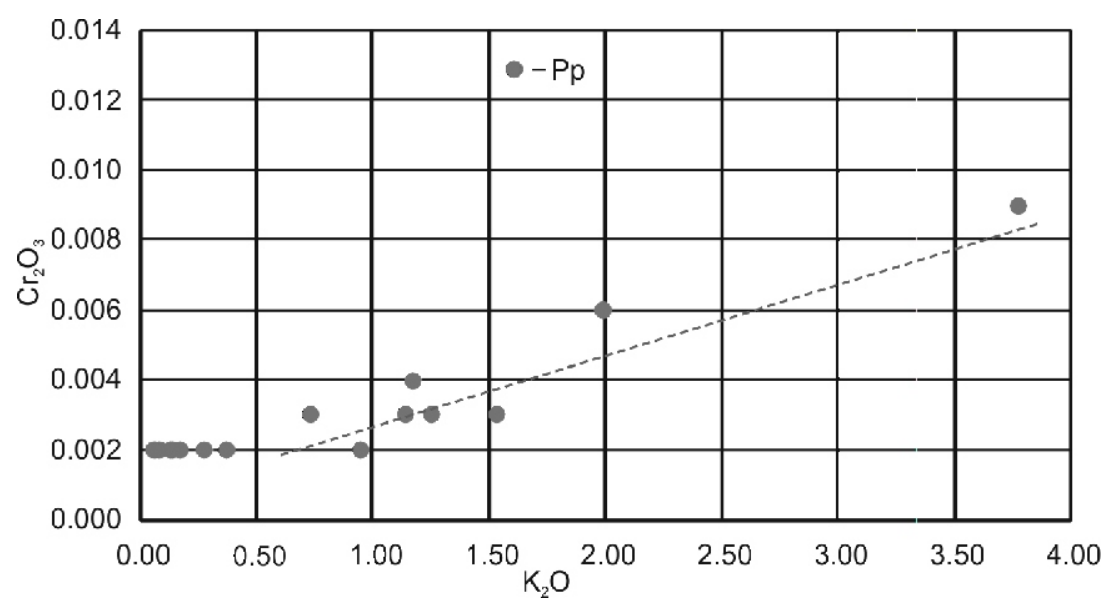

Fig. 20. $\mathrm{Cr}_{2} \mathrm{O}_{3}$ content correlated with $\mathrm{K}_{2} \mathrm{O}$ (in \%) in dolomite replaced by illite (Budy and Piskrzyń quarries)

$\mathrm{Cr}_{2} \mathrm{O}_{3}$ detection limit $0.002 \%$; $\mathrm{Pp}$ - dolomite veined with marcasite

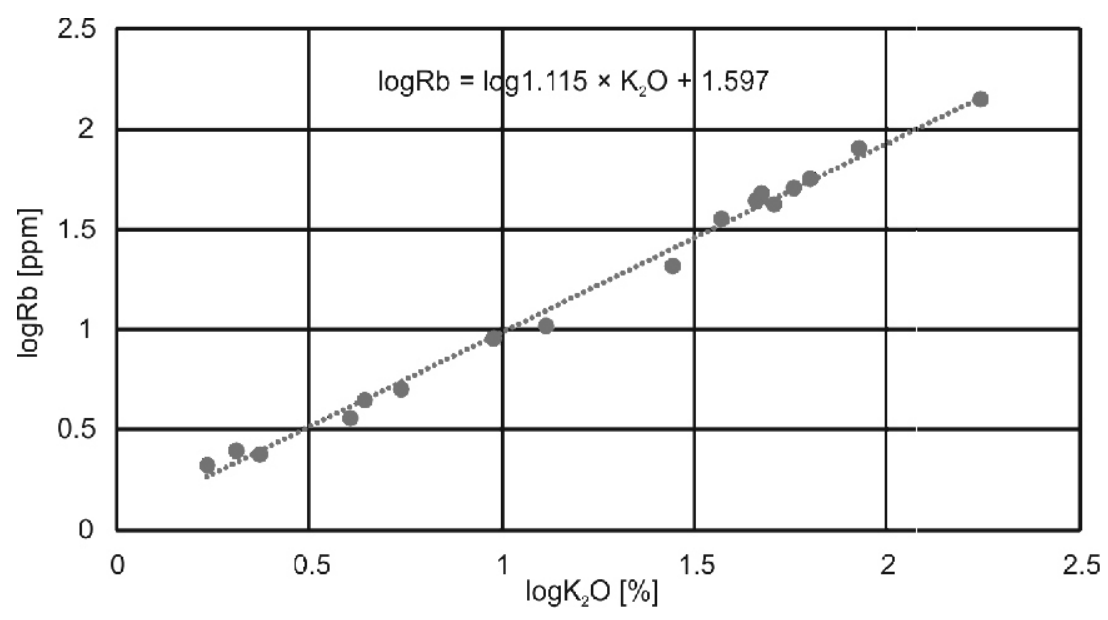

Fig. 21. $\mathrm{K}_{2} \mathrm{O}-\mathrm{Rb}$ content correlation

may be described by equation logRb $(\mathrm{ppm})=\log 1.115$ $\times \mathrm{K}_{2} \mathrm{O}+1.597$, defined by Shaw (1968) for igneous and related rocks. It is considered as an indirect, supporting argument for the magmogenic nature of mineralizing fluids (Ananiew, 2012).

There is a noticeable enrichment of dolomite-illitic rocks in $\mathrm{Zr}$ accompanied by $\mathrm{Ti}$ in places, as well as locally in $\mathrm{Cu}, \mathrm{Zn}, \mathrm{Pb}$, $\mathrm{U}$, Th (Fig. 22), as compared to unaltered dolomite. The $\mathrm{Zn}$ content up to 800-900 ppm, and As content up to 195 ppm, accompanying pyrite-marcasite and hematite mineralization are prominent. Dispersed fine grains of chalcopyrite and sphalerite and minute veinlets of sphalerite are microscopically visible in places. The increased $\mathrm{Zr}$ and $\mathrm{TiO}_{2}$ content (up to $90 \mathrm{ppm}$ and $0.59 \%$, respectively) in llite veins, following alteration of dolomite, suggests their mobility in mineralizing solutions. The hydrothermal mobility of $\mathrm{Zr}$, Ti and accompanying REE, Y, Th and U was formerly noticed close to igneous rocks (Giere, 1990; Rubin et al., 1993). Zr mobility is most common in F-rich hydrothermal fluids and may be promoted by sulphate complexing (Rubin et al., 1993). It is supposed to occur also in potassium rich fluids and favored by $\mathrm{CO}_{2}$ activity (Giere, 1990).
The REE (lanthanide) content varies from a few to about $20 \mathrm{ppm}$ in limestones and unaltered dolomites up to about $126 \mathrm{ppm}$ in dolomite-illitic rocks. The close relationship of the $\mathrm{REE}$ and $\mathrm{K}_{2} \mathrm{O}$ contents (Fig. 23) is remarkable, following the advancement of dolomite replacement by illite. The increased total REE content in the altered dolomites, compared to the parent rocks is clearly expressed (Figs. 24-26). The LREE ${ }^{1}$ predominates over HREE (chondrite-normalized) and the convex PAAS-normalized REE distribution (Figs. 27-29) indicate MREE enrichment, increasing with the advancement of dolomites transformation into dolomite-illitic rocks. The redistribution of these elements is considered to have been governed by diagenetic processes or by migrating fluids (Giere, 1990). In warm and mild acidic brines, $\mathrm{Cl}^{-}, \mathrm{SO}_{4}^{2-}$ and $\mathrm{CO}_{2}$ form complexes with REE, which allow transporting their appreciable amounts (Migdisov et. al., 2016). Varied examples of hydrothermal deposits suggest that hydrothermal processes have concentrated the REE. The predominance of LREE over HREE is the consequence of higher mobility of the former in thermal solutions at low temperatures (Wiliams-Jones, 2015; Migdisov et al., 2016). The high 6-17 La/Lu (chondrite-normal-

\footnotetext{
${ }^{1}$ La to Eu are referred to as LREE, Gd to Lu as HREE and Sm to Dy as MREE
} 


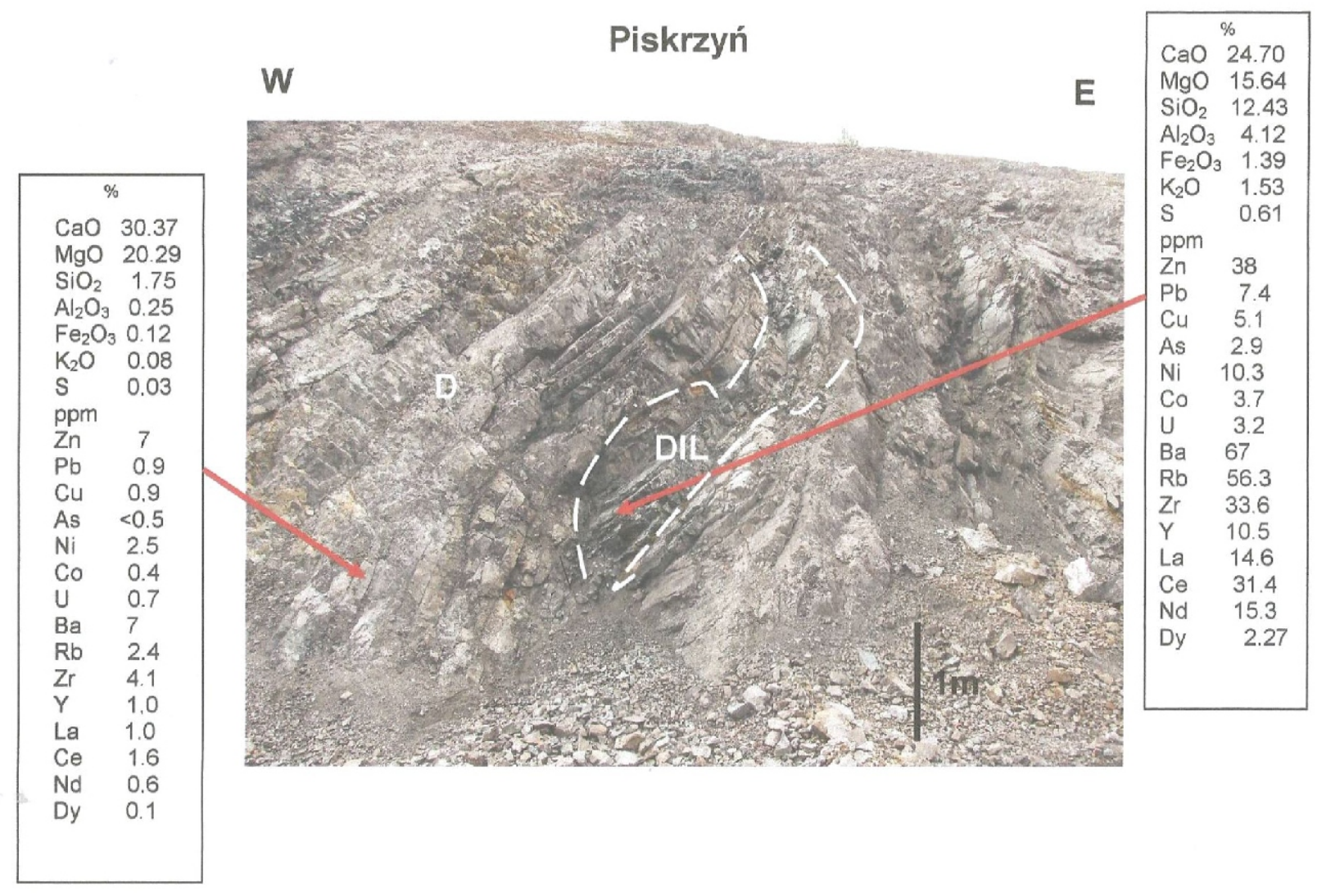

Fig. 22. Varied composition of dolomite replaced by illite (DIL) and not transformed dolomite (D)

Selected chemical compounds, Piskrzyń Quarry, IV level, north

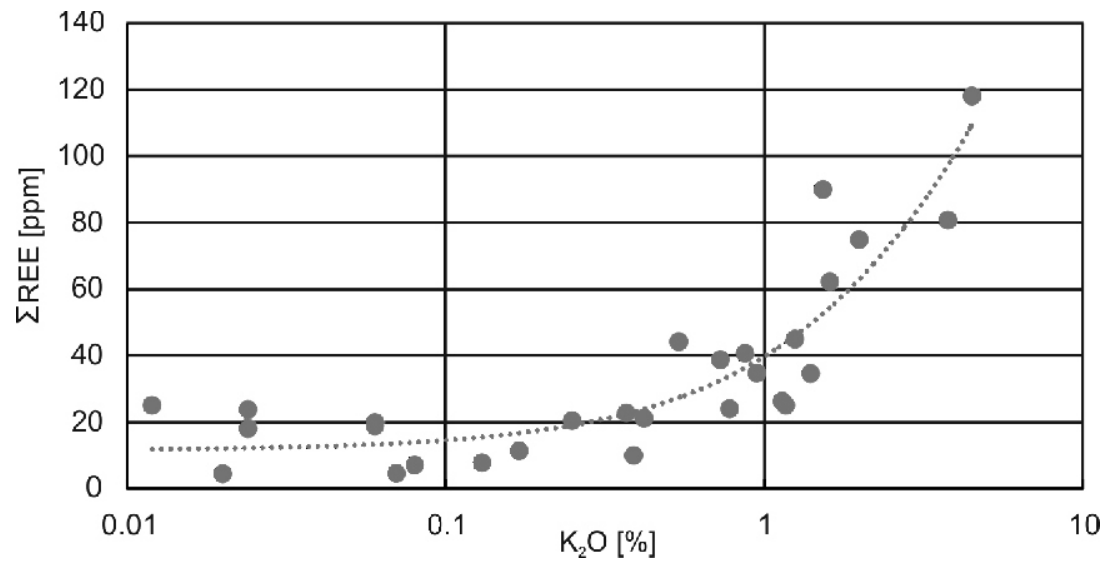

Fig. 23. REE (ppm) correlated with $\mathrm{K}_{2} \mathrm{O}$ content (\%), Piskrzyń and Budy quarries 


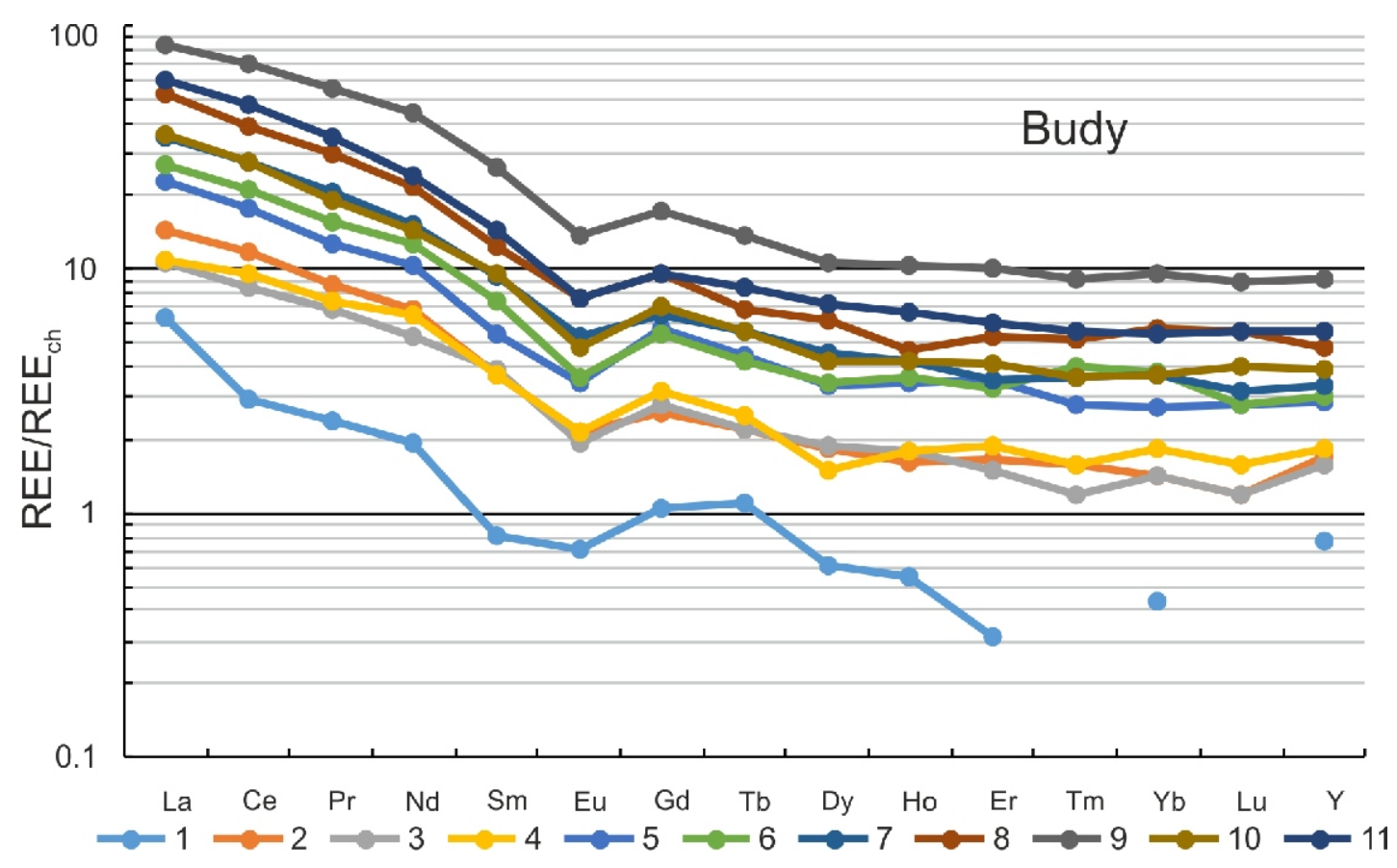

Fig. 24. Chondrite-normalized REE concentration patterns in carbonate rocks, Budy Quarry

For sample numbers see Table 1

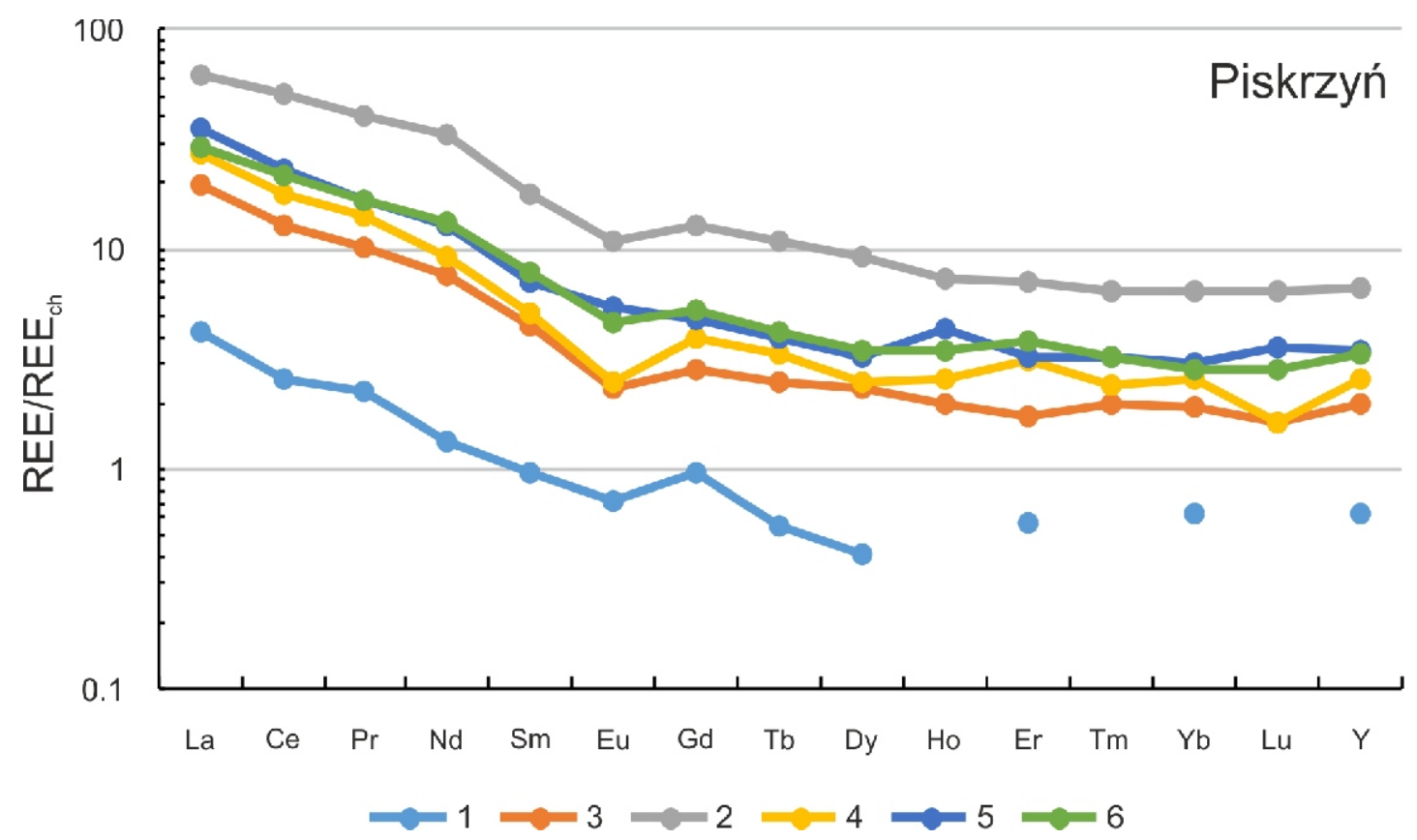

Fig. 25. Chondrite-normalized REE concentration patterns in carbonate rocks, Piskrzyń Quarry

For sample number see Table 2 


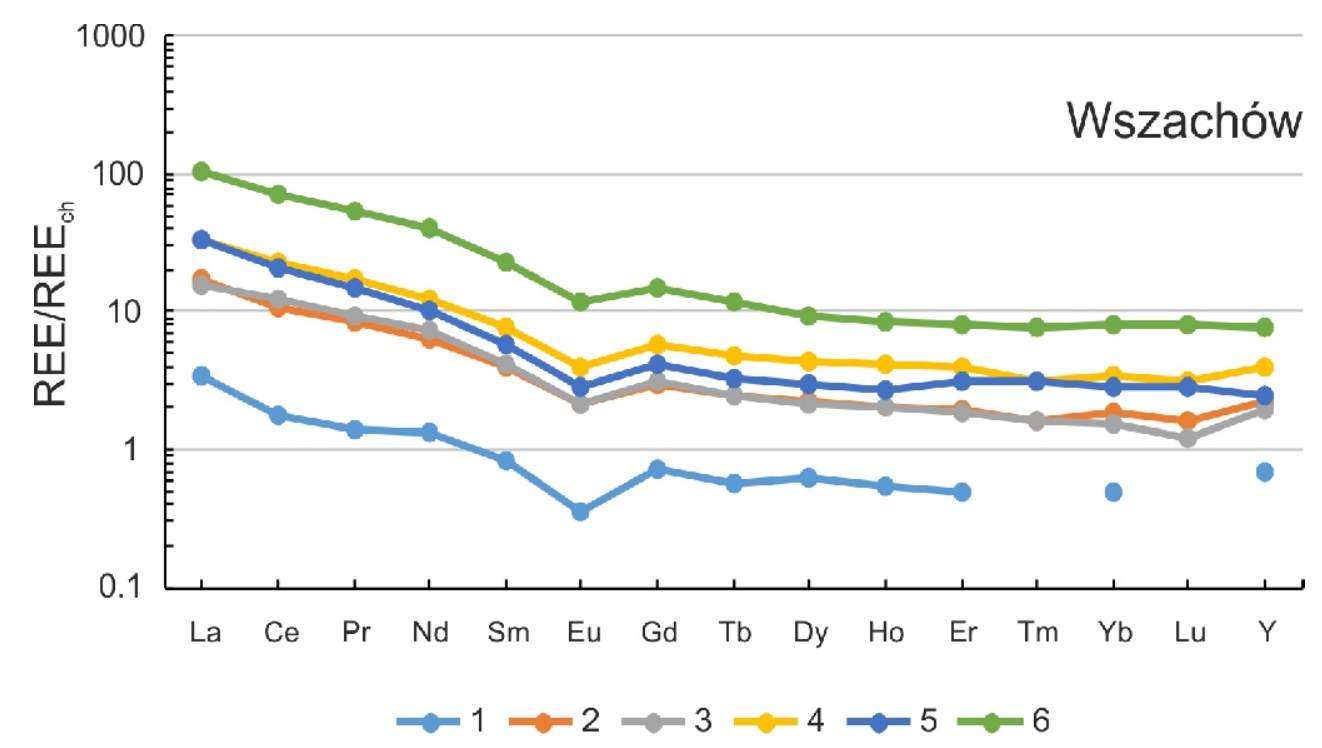

Fig. 26. Chondrite-normalized REE concentration patterns in carbonate rocks, Wszachów Quarry

For sample numbers see Table 3

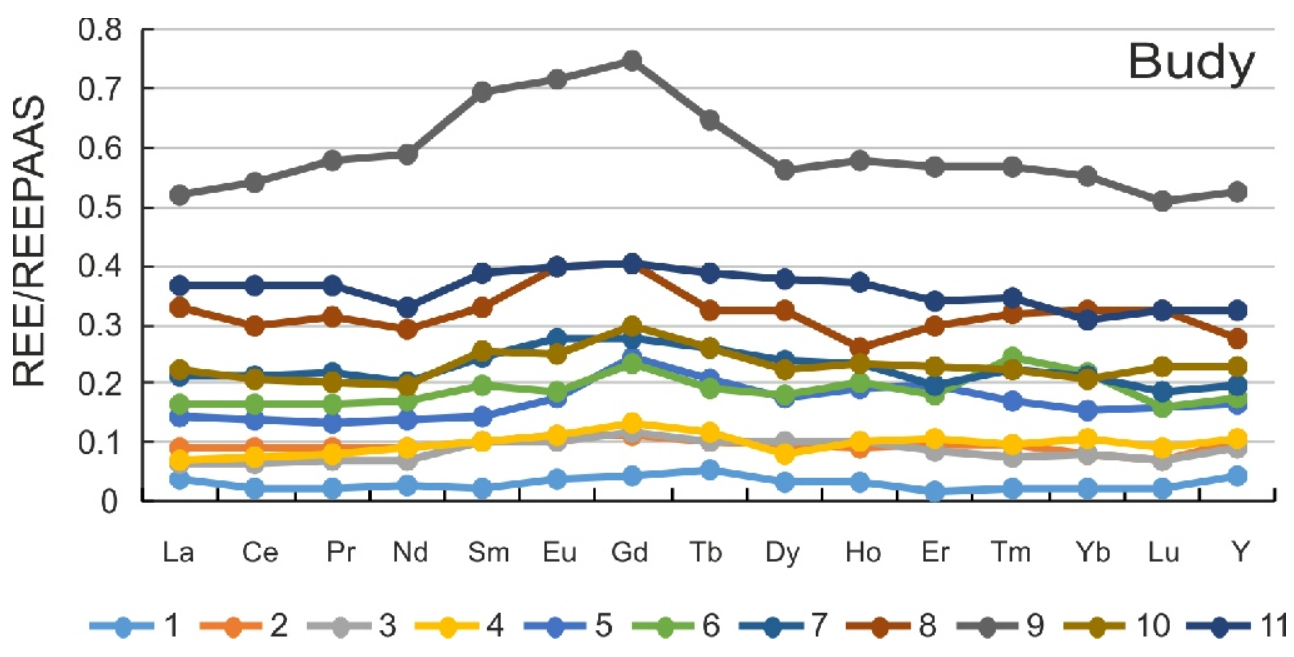

Fig. 27. PAAS-normalized REE concentration patterns in carbonate rocks, Budy Quarry For sample numbers see Table 1

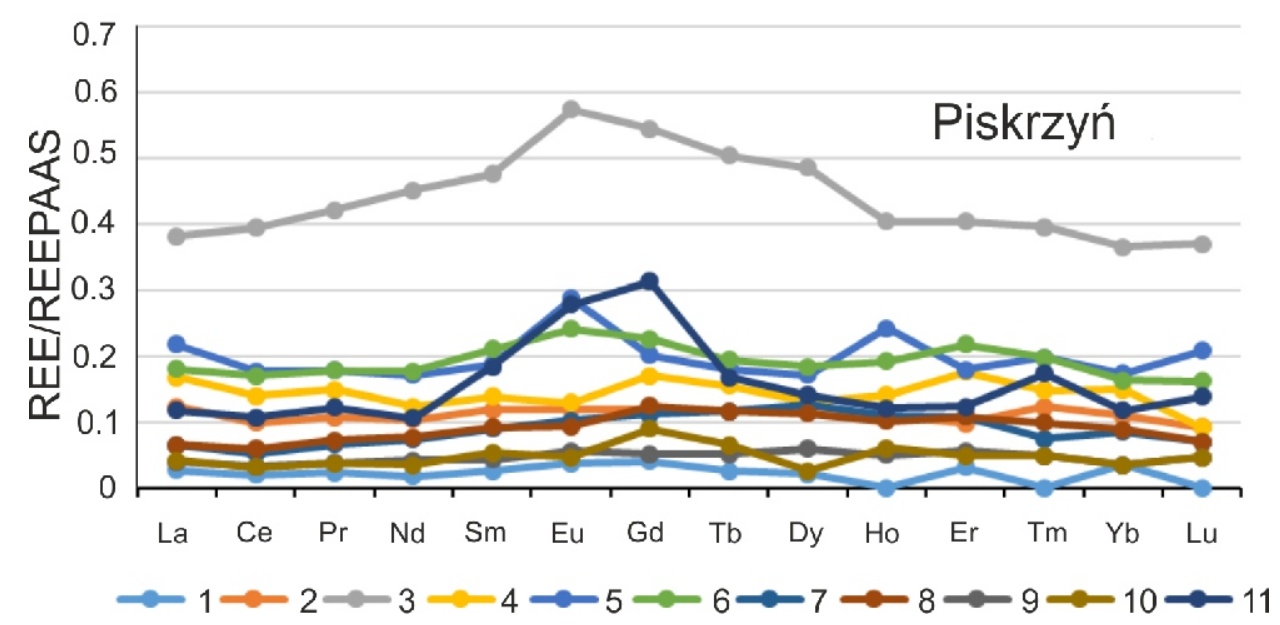

Fig. 28. PAAS-normalized REE concentration patterns in carbonate rocks, Piskrzyń Quarry For sample numbers see Table 2 


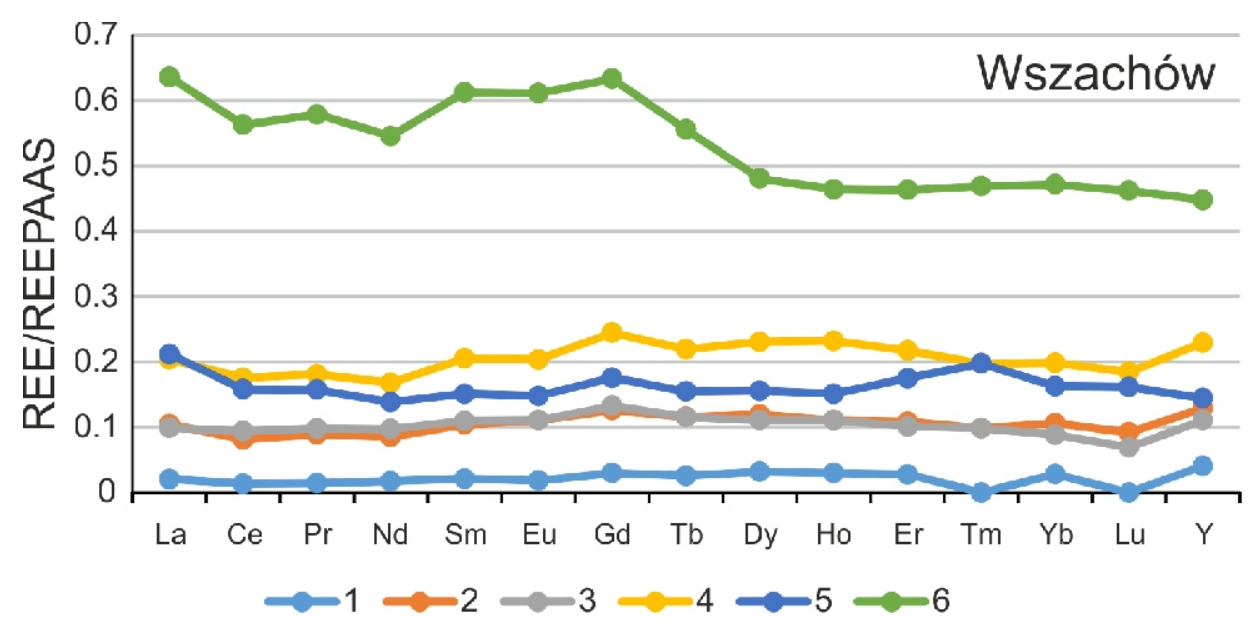

Fig. 29. PAAS-normalized REE concentration patterns in carbonate rocks, Wszachów Quarry

For sample numbers see Table 3

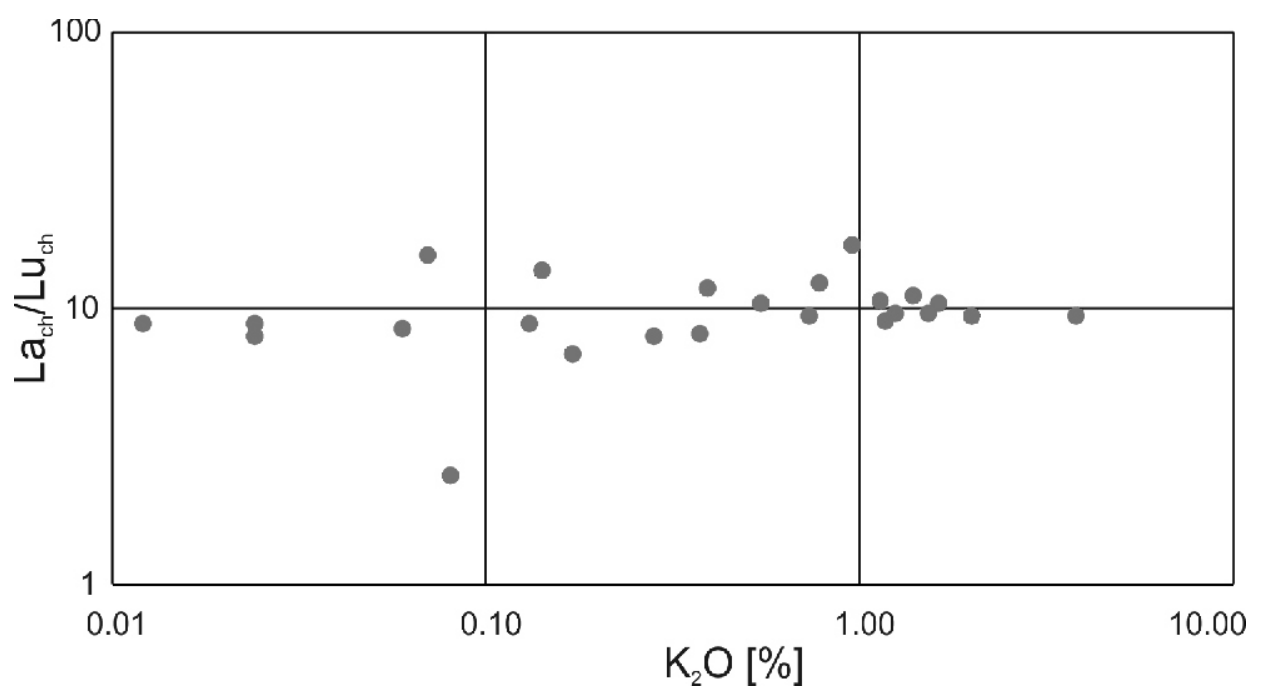

Fig. 30. La/Lu chondrite-normalized in relation to $\mathrm{K}_{2} \mathrm{O}$ content

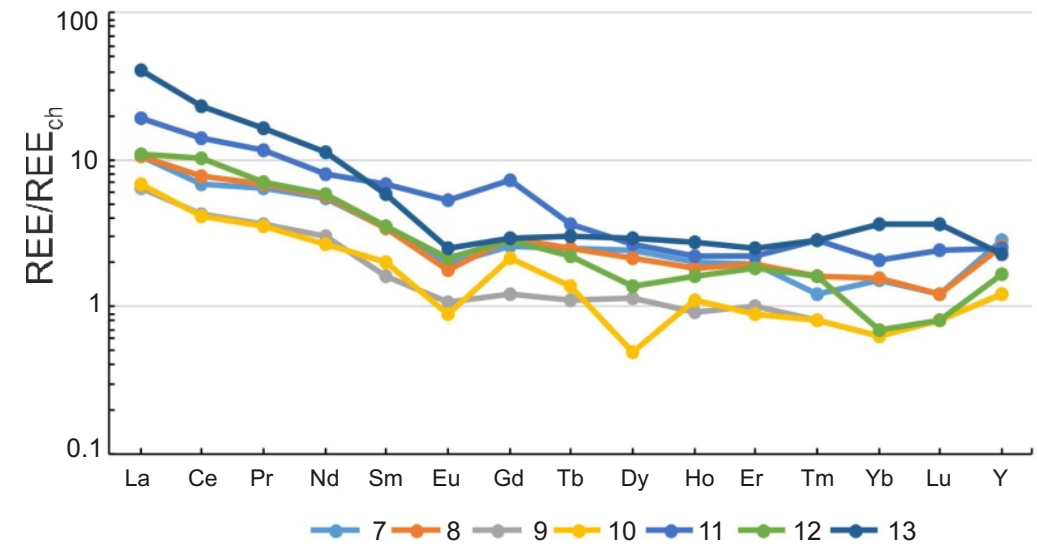

Fig. 31. Chondrite-normalized REE concentration patterns in mineralized rocks in the Budy and Piskrzyń quarries

For sample 7-11 see Table 2, for sample 12 and 13 see Table 1 
ized) ratio demonstrates the clear LREE dominance over HREE and suggests acidic conditions of REE enrichment processes (Bau, 1991). The LREE to HREE ratio, however is not dependent on the $\mathrm{K}_{2} \mathrm{O}$ content (Fig. 30), therefore, it is not affected by the process of dolomite replacement by illite. The $\mathrm{La}_{\mathrm{ch}} / \mathrm{Lu}_{\mathrm{ch}}>1$ is most likely controlled by sorption processes (Bau, 1991).

The total increased REE content in dolomite-illitic rocks suggests their external introduction following a decreased $\mathrm{pH}$ of mineralizing solutions (Michard, 1989; Kučera et al., 2009). The increased $\mathrm{Gd}$ content in relation to the weakly expressed Eu anomaly $\left(\mathrm{Eu} / \mathrm{Eu}^{*} 0.43-0.76\right)$ suggests also that the transformation processes of dolomite into dolomite-illitic rocks took place in a weakly reduced environment. It is proved also by the lack of clear $\mathrm{Ce}$ anomaly (Ce/Ce* $0.75-1.14)$ and replacement of marcasite by pyrite in mineralized zones (Nieć and Pawlikowski, 2015).

The behavior of some HREE is interesting. In the Budy locality, the anomalous, increased contents of $\mathrm{Yb}$ and Lu is observed in iron sulphide-mineralized dolomites and decreased in hematite-bearing ones. Such anomalies, but less prominent, are also observed in Piskrzyń (Fig. 31). The decreased Dy content in hematitized dolomites is remarkable. The varied content of these elements and slightly increased yttrium content allow supposing their mobility during the processes of dolomite rock transformation. The behaviour and fractionation of particular RRE may be explained by local variations of complexing ligands in hydrothermal solutions, such as $\mathrm{CO}_{3}^{2-}, \mathrm{HS}^{-}, \mathrm{SO}_{4}^{2-}$, which are $\mathrm{pH}$-and Eh-dependent (Yongliang and Yusheng, 1991).

\section{DOLOMITE TRANSFORMATION TO DOLOMITE-ILLITIC ROCKS - GENETIC CONSIDERATIONS}

The transformation of dolomite into dolomite-silicate rock by the introduction of silica and often iron and other metal (e.g., $\mathrm{Cu}, \mathrm{Zn}$ ) sulphides is a well-studied process accompanying igneous intrusions,. The effect of such high temperature processes is the formation of diopside-epidote-wollastonite skarns close to the sidewalls of acid and intermediate magmatic rock intrusions, often containing magnetite or Fe-Zn-Cu ores, well described in ore geology textbooks (e.g., Misra, 2000). At lower temperatures, serpentinization of dolomites occurs (Kowalski, 1962; Lewandowska, 1991; Muszyński and Wyszomirski, 1998), but it is less common. Dolomite silicification is often observed in the hydrothermal environment. The formation of talk deposits also take place but it is a rarer process (Tornos, 2000; Boulvais et al., 2006; Wölfler et al., 2015). The replacement of dolomite by illite was noticed by Zalba et al. (2010a, b) in some stromatolite dolostone beds in the mixed carbonate-siliciclastic sequences in the Tandilia Basin, Argentina. Illite is accompanied by rutile, and by precipitation of hematite, goethite, pyrite and quartz. The illuvial introduction of clay, during temporal weathering, and further burial diagenetic origin of dolomite-illitic rocks are supposed there. However the tectonic disturbances (fracture network system filled with reddish clays, slickensides, brecciation) and the proximity to the cross faults, allow admitting also the post diagenetic hydrothermal replacement of dolomite by illite and accompanying minerals. The widespread occurrence of dolomite-illitic rocks independently of sedimentary features and linked with tectonic disturbances, observed in the Holy Cross Mts. is the exceptional phenomenon.

The accumulation of clay minerals which accompanies epigenetic dolomitization, was remarked by Migaszewski (1990) in the western part of the Holy Cross Mts. Based on the mode of their occurrence, petrographic features of altered rocks, and oxygen isotopes composition, he demonstrated its hydrothermal origin and suggested their formation due to synsedimentary smoker's activity. Field data, however, make the smokers hypothesis disputable (Narkiewicz et al., 2006). The presence of altered dolomites close to the zones of brecciated rocks suggest their association with tectonic disturbances. The above-presented mode of appearance of similar rocks in the eastern part of the Holy Cross Mts. in the fault zones and their close vicinity, and the spatial association with the marcasite-pyrite-hematite mineralization, strongly support such a supposition.

The parent rocks transformed to dolomite-illitic ones are dolomites, formed by epigenetic regional dolomitization of Middle Devonian limestones, through the action of magnesium-rich bassinal brines, at about $100^{\circ} \mathrm{C}$ (Narkiewicz et al., 2006; Narkiewicz, 2009). The irregular dolomitization front, best visible in the Budy Quarry proves the post-lithification process. The dolomites have varied petrographic features, partly inherited from limestone palaeosome. They are most often micro- to medium-crystalline (sparites), and show a mosaic fabric. The further replacement of dolomite by illite was preceded by recrystallization of dolomite and the formation of a coarsely crystalline rock of saccharoidal appearance. Iron sulphide (marcasite-pyrite) and hematite mineralization accompanies illite in the final stage of dolomite replacement. Such mineralization also appears in the fractured or fault-dissected dolomites, beyond the dolomite-illitic rocks, but close to them.

The mode of occurrence of dolomite-illitic rocks indicate that their formation postdate epigenetic dolomitization of limestone. It started probably simultaneously with the final stage of main tectonic activity postdating it. The hydrothermal nature of the rocks was demonstrated by Migaszewski (1990) based on the oxygen-isotopes composition, and the formation at the temperature of $80-115^{\circ} \mathrm{C}$. The silicification of dolomite observed in other localities took place at $100-200^{\circ} \mathrm{C}$ (Migaszewski et al., 1999). Illite crystallinity suggest the temperature of formation over $150^{\circ} \mathrm{C}$. The process of dolomite transformation into dolomite-illitic rocks started by dolomite recrystallization, accompanied and followed by illite precipitation in interstitial space and partial corrosion of dolomite metacrysts, with the almost simultaneous precipitation of iron sulphides or hematite according to the local $\mathrm{pH}$ and Eh conditions. The coexistence of disseminated iron sulphide and hematite in dolomite illitic rock may be explained by their formation close to a redox front. It is supported by the presence of marcasite-hematite mineralization in the nearest vicinity (Nieć and Pawlikowski, 2015). The increased MREE content suggests the low $\mathrm{pH}$ of mineralizing solutions, probably rich in sulphate, which form MREE-sulphite ligands more stable compared with LREE and HREE, and allow their greater mobility, and stabilization through $\mathrm{pH}$ neutralization by carbonates (Johannesson et al., 1996; Migdisov et al., 2016).

The formation of dolomite-illitic rocks was possible due to the introduction of considerable quantities of silica, alumina and potassium. The REE content, higher than in unaltered dolomites, can be explained by large volume of fluids involved (Quing and Mountjoy, 1994). The source of Si, Al, K and REE may be the claystones, forming intercalations present within or below the limestone-dolomite rock series, or such source should be searched beyond. This may be either the lamprophyre intrusions or the deep-seated magmatic source of both lamprophyres and hydrothermal solutions. Numerous lamprophyre and altered diabase vein intrusions are present south of the dolomite-illitic rocks in Wszachów and Piskrzyń (Fig. 32) and NE from Budy (in the northern part of the Klimontów anticlinorium and the southern part of the Łagów synclinorium). 


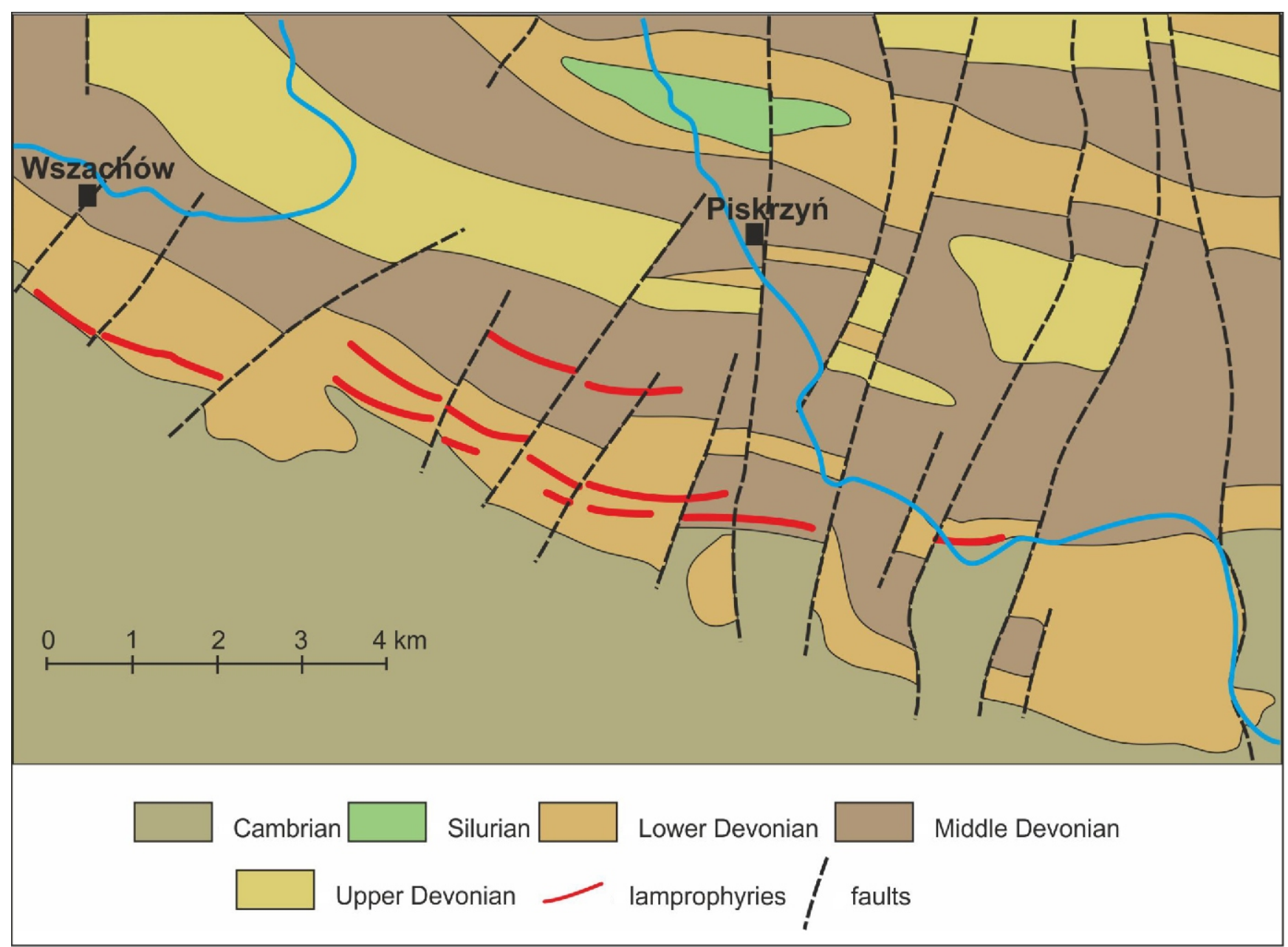

Fig. 32. Geology of the area between Wszachów and Piskrzyń (after Walczowski, 1968; Dowgiałło, 1974)

The hydrothermal reprecipitation of illite is demonstrated e.g., in the neighborhood of mafic rock intrusions in Tunisia (Mattoussi Kort et al., 2008). The registered elevated chromium content in the studied dolomite-illitic rocks suggests the link of hydrothermal processes with intrusions of such rocks. Advocate for it known other occurrences of chromium containing illite (chrom-illite - "avalite"2). It was encountered in hydrothermally altered serpentinite (Maksimowic and Brindley, 1980), in serpentine hosting cinnabar deposits (Maugin, 1956) and in streaks and veinlets in association with uranium mineralization, formed by hydrothermal solutions penetrating sandstones (Kerr and Hamilton, 1958).

The association of hydrothermal activity with intrusions of lamprophyres and diabases in the Holy Cross Mts. was suggested earlier by Rubinowski (1969) and the association with diabase intruded at 331-323 Ma was suggested by Nawrocki et al. (2013). Disseminated Zn, Pb, and Fe sulphides were noticed within the sidewalls of lamprophyre veins in the Cambrian and Devonian mudstones (Pawłowska, 1958; Nowakowski, 1959; Rubinowski, 1966). The lamprophyre intrusion within the Devo- nian carbonates west of Piskrzyń is surrounded by friable dolomite, partly altered into "clay-silica-carbonates and siderite-dolomite" rock, and cut by chlorite-quartz- carbonate veinlets with Fe and Pb sulphides (Tarnowska, 1967, 1974). A dyke of hydrothermally altered, adularized mafic rock, highly enriched in potassium up to $8.86 \%$, was found northeast of Budy (Nowakowski, 1959). It demonstrates the activity of potassium-rich hydrothermal fluids.

The study of organic matter in the Devonian rocks in the Holy Cross Mountains demonstrates its maturity at $120-160^{\circ} \mathrm{C}$ and the existence of the "Variscan thermal anomaly" of elevated heat flow in the Holy Cross fault zone (Belka, 1990; Marynowski, 1999; Narkiewicz et al., 2006). In the deep borehole Jańczyce 1, located west of Piskrzyń, a distinct depth-related increase in kerogen maturity was detected, which suggests a deep-seated heat source (Marynowski, 1999). It may be the source of hydrothermal fluids. The fractured rocks in fault sidewalls were good pathways for hydrothermal solutions. Limestones and synsedimentary or epigenetic dolomites commonly present in Middle Devonian carbonate complexes were hydrothermally

\footnotetext{
${ }^{2}$ The name not recognized by International Mineralogical Union (Manecki, 2004)
} 
transformed. Epigenetic dolomitization was the process of regional extension during the Carboniferous, before the main Variscan tectonic activity (Narkiewicz et al., 2006). Iron sulphide, siderite and hematite mineralization in the Holy Cross Mts. predates the early Permian (Rubinowski, 1966). The dolomite recrystallization, formation of dolomite-illitic rocks and marcasite-pyrite-hematite mineralization controlled by faulting and folding may be simultaneous with the main phase of tectonic activity or postdate it. The accompanying numerous, variously oriented generations of dolomite-ankerite-siderite veins demonstrate that the mineralization was a multistage process.

The wide spreading of alterations of dolomite and marcasite-pyrite-hematite, as well as siderite-ankeritic mineralization all over the area of the Holy Cross Mts., allow us to suppose the deep-seated source of both hydrothermal solutions and lamprophyre and diabase veins. The increased contents of REE and other metals in altered dolomites is the interesting, phenomenon as a possible fingerprint of hydrothermal processes in the aureole of ore deposits that may be located at large depth.

\section{CONCLUSIONS}

The widespread occurrence of dolomite-illitic rocks, the hydrothermal origin of which is presented, proves regional hydrothermal activity in the Holy Cross Mts. at the final stage of the Variscan orogeny. The source of hydrothermal solutions is not clear, but their link with lamprophyre intrusions or some unknown deep-seated magmatic source seems the most probable. The occurrence of dolomite-illitic rocks close to marcasite-hematite mineralization suggests that they may be a guide to some deep-seated, yet unknown ore deposits.

Acknowledgments. Authors thank the Management Staff of "Kopalnie Dolomitu Co." in Sandomierz and of the quarries for the kind allowance for multiple visits to the studied quarries and for help in the fieldwork. We thank Dr. eng. E. Sermet for her help in the field. Special thanks are due to Reviewers for valuable critical remarks and suggested corrections.

\section{REFERENCES}

Ananiew, J.S., 2012. Redkozemelnyye elementy $v$ metasomatitakh i rudakh zolotorudnykh mestorozdienii Kalby. Izwiestiya Tomskogo Politekhnicheskogo Universiteta, 321: $56-62$.

Antoniuk, J., Górecki, J., Mościcki, W., Szwed, E., 2005. Geophysical support of documentation of carbonate rock deposits in the Świętokrzyskie Mts. (in Polish with English summary). Prace Naukowe Politechniki Wrocławskiej, 109: 3-12.

Bau, M., 1991. Rare earth element mobility during hydrothermal and metamorphic fluid-rock intraction and the significance of the oxidation state of europium. Chemial Geology, 93: 219-230.

Bąk, B., Nieć, M., 1979. Allophanes from Zn-Pb sulphide ore deposit at Bolesław Mine, Poland. Mineralogia Polonica, 10: 89-97.

Belka, Z., 1990. Thermal maturation and burial history from conodont color alteration data, Holy Cross Mountains, Poland. Courier Forschunginstitut Senckenberg, 11: 241-251.

Boulvais, P., de Parseval, P., D'hulst, A., Paris P., 2006. Carbonate alteration associated with talc-chlorite mineralization in the eastern Pyrenees, with emphasis on the St. Barthelemy Massif. Mineralogy and Petrology, 88: 499-526.

Chlebowski, R., Rubinowski, Z., 1970. Dickite mineralization in the Świętokrzyskie Mts. (in Polish with English summary). Kwartalnik Geologiczny, 14 (3): 411-426.

Dowgiałło, W.D., 1974. Objaśnienia szczegółowej mapy geologicznej Polski 1:50 000, arkusz Opatów (in Polish). Instytut Geologiczny, Warszawa.

Giere, R., 1990. Hydrothermal mobility of Ti, Zr and REE: examples from the Bergell and Adamello Contact Aureoles (Italy). Terra Nova, 2: 60-67.

Heyl, A.V., Hosterman, J.W., Brock, M.R., 1964. Clay mineral alteration in the Upper Mississippi Valley zinc-lead district. In: Clays and Clay Minerals - proceedings of 12th National Conference on Clay and Clay Minerals, Atlanta, Georgia, September 30-October 2, 1963: 445-453. Macmillan, New York.

Hosterman, J.W., Heyl, A.V., Jolly, J.L., 1964. Quantitative X-ray emission analysis studies of enrichment of common elements in wallrock alteration in the Upper Mississippi Valley zinc-lead district. Geological Survey Research 1964, Chapter D: 54-60.

Jaskólski, S., Poborski, Cz., Goerlich, E., 1953. Złoże pirytu i rud żelaznych kopalni „Staszic” w Górach Świętokrzyskich (in Polish). Wyd. Geol., Warszawa.
Johannesson, K.H., Lyons, W.B., Yelken, M.A., Gaudette, H.E., Stetzenbach, K.J., 1996. Geochemistry of rare earth elements in hypersaline and dilute acidic neutral terrestrial waters: complexation behavior and middle rare earth element enrichment. Chemical Geology, 133: 125-144.

Junfeng, J., Brown, P.R.L., 2000. Relationship between illite crystallinity in active geothermal systems of New Zeeland. Clays and Clay Minerals, 41: 139-144.

Kerr, P.F., Hamilton, P.K., 1958. Chrome mica-clay, Temple Mountain, Utah. The Americam Mineralogist, 43: 34-47.

Konon, A., 2006. Młodopaleozoiczna ewolucja strukturalna Gór Świetokrzyskich (in Polish). LXVII Zjazd PTG w Kielcach: 82-104. Państwowy Instytut Geologiczny, Warszawa.

Kowalski, W., 1962. Serpentinization in the arsenic ore deposit at Złoty Stok (Lower Silesia) (in Polish with English summary). Prace Geologiczne PAN, 12: 55-77.

Kučera, J., Cempirek, J., Dolniček, Z., Muchez, P., Prochaska, W., 2009. Rare earth elements and yttrium geochemistry of dolomite from post-Variscan vein type mineralization of the Nizky Jesenik and Upper Sand Upper Silesian Basins, Czech Republic. Journal of Gechemical Explpration, 103: 69-79.

Lewandowska, A., 1991. Minerals of the zone of altered Devonian dolomites from Dubie area near Kraków (Sothern Poland). Mineralogia Polonica, 22: 20-38.

Lovering, T.S., Shepard, A.O., 1960. Hydrothermal alteration zones caused by halogen acid solutions, East Tintic, Utah. American Journal of Science, 258-A: 215-229.

Lögters, H., 1944. Die Siderit-Pyrit-Hemait-Hematit Lagerstätte "Staszic" bei Słupia Nowa in den Hellig Kreuzgbirgen (Polonisches Mittelgebirge). Zeitschrift. für Praktische Geologie, 9: 83-96.

Maguin, M.C., 1956. Sur la presence d'illite chromifère dans le gisement de cinabre d'Avala, près de Belgrade. Compte Rendus, 242: 145-147.

Maksimovic, Z., Brindley, G.W., 1980. Hydrothermal alteration of a serpentinite near Takovo, Yougoslavia, to chromium-bearing illite/smectite, kaolinite, tosudite, and haalloysite. Clays and Clay Minearls, 28: 295-302.

Manecki, A., 2004. Encyklopedia minerałow (in Polish). Wyd. AGH, Kraków. 
Marynowski, L., 1999. Thermal maturity of organic matter in w Devonian rocks of the Holy Cross Mts. (central Poland) (in Polish with English summary). Przegląd Geologiczny, 47: 1125-1129.

Mattoussi Kort, H., Beji Sassi, A., Laridhi Ouazaa, N., 2008. Thermal and hydrothermal influence of magmatic emissions on embedded clays of the Upper Cretaceous of the Tunisian eastern margin and the Pelagic sea. C. R. Geoscience, 340: 298-305.

Michard, A., 1989. Rare earth element systematics in hydrothermal fluids. Geochimica et Cosmochimica Acta, 53: 745-750.

Migaszewski, Z., 1990. Synsedimentary hydrothermal deposits of the Middle and Upper Devonian in the Góry Świętokrzyskie Mts. (in Polish with English summary). Prace Państwowego Instytutu Geologicznego, 129: 1-55.

Migaszewski, Z., 1991. Devonian dolomites from the Holy Cross Mts. Poland: a new concept of the origin of massive dolomites based on petrographic and isotopic evidence. Journal of Geology, 99: 171-187

Migaszewski, Z., Salwa, S., Durakiewicz, T., 1999. Devonian and Carboniferous siliceous rocks of the Holy Cross Mts. - a new concept of the origin (central Poland) (in Polish with English summary). Przegląd Geologiczny, 47: 818-824.

Migdisov, A., Williams-Jones, A.E., Brugger, J., Caporuscio, F.A., 2016. Hydrothermal transport, deposition, and fractionation of the REE: experimental data and thermodynamic calculations. Chemical Geology, 439: 13-42.

Misra, K.C., 2000. Understanding Mineral Deposits. Kluwer Academic Press, Dordreht, Boston, London.

Muszyński, M., Wyszomirski, P., 1998. Contact alterations of Devonian carbonate rocks in the vicinity of Dubie near Cracow (in Polish with English summary). Geologia, Kwartalnik AGH, 24 199-217.

Narkiewicz, M., 1991. Mezogenetic dolomitization processes: an example from the Givetian and Frasnian of Holy Cross Mountains, Poland (in Polish with English summary). Prace Państwowego Instytutu Geologicznego, 82: 1-54.

Narkiewicz M., 2009. Late burial dolomitization of the Devonian carbonates and $\mathrm{s}$ tectono-thermal evolution of the Holy Cross Mts. area (Central Poland). Mineralogia - Special Papers, 35: 51-59.

Narkiewicz, M., Racki, G., Skompski, S., Szulczewski, M., 2006 Zapis procesów i zdarzeń w dewonie i karbonie Gór Świętokrzyskich (in Polish). LXVII Zjazd PTG w Kielcach: 51-77. Państwowy Instytut Geologiczny, Warszawa.

Nawrocki, J., Salwa, S., Pańczyk, M., 2013. New ${ }^{40} \mathrm{Ar}-{ }^{39} \mathrm{Ar}$ age constrains of magmatic and hydrothermal activity in the Holy Cross Mts. (southern Poland). Geological Quarterly, 57 (3) 551-560.

Nieć, M., 1968. Mineralization of the deposit of iron sulphides and siderite at Rudki in the Holy Cross Mountains (in Polish with English summary). Prace Geologiczne PAN, 46: 1-124.

Nieć, M., Pawlikowski, M., 2015. Marcasite-hematite-ankerite mineralization in the south-Eastern part of Holy Cross Mts. (Poland) (in Polish with English summary). Przegląd Geologiczny, 63: 219-227.

Nowakowski, A., 1959. On the adularized dyke rock in the vicinity of Klimontów (Holy Cross Mts.). Bulletin de l'Académie Polonaise des Science. Serie Chimica, Geologica et Geographica, 7: 751-757.
Pawłowska, J., 1958. Novel data on lamprophyres from the region of Iwaniska in the Święty Krzyż Mountains (in Polish with English summary). Kwartalnik Geologiczny, 2 (4): 688-705.

Quing, H., Mountjoy, E.W., 1994. Rare earth elemnt geochemistry of dolomites in then Middle Devonian Presq'ile Western Canada Sedimentary Basin: implications for fluid-rock ratio during dolomitization. Sedimentology, 41: 787-804.

Romanek, A., 1977. Objaśnienia szczegółowej mapy geologiczne Polski 1:50 000, arkusz Klimontów (in Polish). Instytut Geologiczny, Warszawa.

Rubin, J.N., Henry, Ch.D., Price, J.G., 1993. The mobility of zirconium and other "immobile" elements during hydrothermal alteration. Chemical Geology, 110: 29-47.

Rubinowski, Z., 1966. Metalogeneza trzonu paleozoicznego Gór Świętokrzyskich (in Polish). Prace Instytutu Geologicznego.

Rubinowski, Z., 1969. Pozycja mineralizacji syderytowo-pirytowej w metalogenezie trzonu plaeozoicznego Gór Świętokrzyskich (in Polish). Rocznik PTG, 39: 721-722.

Shaw, D.M., 1968. A review of $\mathrm{K}-\mathrm{Rb}$ fractionation trends by covariance analysis. Geochimica and Cosmochimica Acta, 32: 573-601.

Tarnowska, M., 1967. Mineralizacja i przeobrażenia kontaktowe towarzyszące lamprofirom z wierceń: Wszachów 1 i 2 oraz Iwaniska 3 (in Polish). Kwartalnik Geologiczny, 11 (2): 462-463.

Tarnowska, M., 1974. Lamprophyre in the Middle Devonian of the Góry Świętokrzyskie Mts. (in Polish with English summary). Biuletyn Instytutu Geologicznego, 275: 63-90.

Tornos, F., 2000. The geology and isotope geochemistry of the talc deposits of Puebla de Lilo (Cantabrian Zone, Northern Spain) Economic Geology, 95: 1277-1296.

Walczowski, A., 1968. Objaśnienia do szczegółowej mapy geologicznej Polski 1:50 000, arkusz Łagów (in Polish). Instytut Geologiczny, Warszawa.

Wiliams-Jones, A.E., 2015. The hydrothermal mobility of the rare earth elements. Symposium on critical and strategic materials. British Columbia Geological Survey Paper, 2015-3: 119-123.

Wölfler, A., Prochaska, W., Fritz, H., 2015. Shear zone related talc mineralization in the Veitsch nappe of the Eastern Greywacke Zone (Eastern Alps). Austrian Journal of Earth Science, 108: 50-72.

Yates, D.M., Rosenberg, P.E., 1998. Characterization of neoformed illite from hydrothermal experiments at $250^{\circ} \mathrm{C}$ and $\mathrm{P}_{\mathrm{v} \text { soln }}$ : An HRTEM/ATM study. American Mineralogist, 83: 1199-1208.

Yongliang, X., Yusheng, Z., 1991. The mobility of rare earth elements during hydrothermal activity: a review. Chinese Journal of Geochemistry, 10: 295-306.

Zalba, P.E., Manassero, M., Morosi, M.E., Canconi, M.S., 2010a Preservation of biogenerated mixed facies: a case study from the Neoproterozoic Villa Monica formation, Sierra La Juanita, Tandilia, Argentina. Journal of Applied Sciences, 10: 363-379.

Zalba, P.E., Morosi, M.E., Manassero, M., Canconi, M.S., 2010b. Microscale diagnostic diagenetic features in Neoproterozoic and Ordovician units, Tandilia basin, Argentina. Journal of Applied Sciences, 10: 2754-2772. 